\title{
A new model of meteoric calcium in the mesosphere and lower thermosphere
}

\author{
John M. C. Plane ${ }^{1}$, Wuhu Feng ${ }^{1,2}$, Juan Carlos Gómez Martín ${ }^{1,3}$, Michael Gerding ${ }^{4}$, and Shikha Raizada ${ }^{5}$ \\ ${ }^{1}$ School of Chemistry, University of Leeds, Leeds LS2 9JT, UK \\ ${ }^{2}$ National Centre for Atmospheric Science, School of Earth and Environment, University of Leeds, Leeds LS2 9JT, UK \\ ${ }^{3}$ Instituto de Astrofísica de Andalucía (IAA-CSIC), 18008 Granada, Spain \\ ${ }^{4}$ Leibniz Institute of Atmospheric Physics, Rostock University, Schlossstraße 6, 18225 Kühlungsborn, Germany \\ ${ }^{5}$ Space and Atmospheric Science Department, Arecibo Observatory/SRI International, Arecibo 00612, Puerto Rico
}

Correspondence: John M. C. Plane (j.m.c.plane@leeds.ac.uk)

Received: 16 May 2018 - Discussion started: 22 May 2018

Revised: 29 September 2018 - Accepted: 4 October 2018 - Published: 16 October 2018

\begin{abstract}
Meteoric ablation produces layers of metal atoms in the mesosphere and lower thermosphere (MLT). It has been known for more than 30 years that the $\mathrm{Ca}$ atom layer is depleted by over 2 orders of magnitude compared with $\mathrm{Na}$, despite these elements having nearly the same elemental abundance in chondritic meteorites. In contrast, the $\mathrm{Ca}^{+}$ ion abundance is depleted by less than a factor of 10 . To explain these observations, a large database of neutral and ionmolecule reaction kinetics of $\mathrm{Ca}$ species, measured over the past decade, was incorporated into the Whole Atmosphere Community Climate Model (WACCM). A new meteoric input function for $\mathrm{Ca}$ and $\mathrm{Na}$, derived using a chemical ablation model that has been tested experimentally with a Meteoric Ablation Simulator, shows that $\mathrm{Ca}$ ablates almost 1 order of magnitude less efficiently than Na. WACCM-Ca simulates the seasonal Ca layer satisfactorily when compared with lidar observations, but tends to overestimate $\mathrm{Ca}^{+}$measurements made by rocket mass spectrometry and lidar. A key finding is that $\mathrm{CaOH}$ and $\mathrm{CaCO}_{3}$ are very stable reservoir species because they are involved in essentially closed reaction cycles with $\mathrm{O}_{2}$ and $\mathrm{O}$. This has been demonstrated experimentally for $\mathrm{CaOH}$, and in this study for $\mathrm{CaCO}_{3}$ using electronic structure and statistical rate theory. Most of the neutral Ca is therefore locked in these reservoirs, enabling rapid loss through polymerization into meteoric smoke particles, and this explains the extreme depletion of $\mathrm{Ca}$.
\end{abstract}

\section{Introduction}

Layers of metal atoms and ions occur in the Earth's mesosphere and lower thermosphere (MLT, between 70 and $120 \mathrm{~km}$ ) as a result of meteoric ablation (Plane et al., 2015). A layer of $\mathrm{Ca}^{+}$ions was first observed in the twilight glow more than 60 years ago (Vallance-Jones, 1956). Istomin (1963), 7 years later, used rocket-borne mass spectrometry to show that these ions occurred in a broad layer peaking around $100 \mathrm{~km}$. A number of sounding rocket measurements of metallic ions in the MLT have been made subsequently (Kopp, 1997; Grebowsky and Aikin, 2002). The neutral Ca layer was first observed in 1985 by the resonance lidar technique and shown to peak around $90 \mathrm{~km}$ (Granier et al., 1985). Since then, a relatively small number of lidar studies of $\mathrm{Ca}$ and $\mathrm{Ca}^{+}$(which uniquely among the meteoric metal ions can be observed by ground-based lidar) have been performed (Alpers et al., 1996; Gerding et al., 2000; Granier et al., 1989; Qian and Gardner, 1995; Raizada et al., 2011, 2012).

When compared to the $\mathrm{Na}$ and Fe layers, which have been much more widely studied, three features stand out (Plane, 2011). First, the atomic $\mathrm{Ca}$ abundance is depleted by a factor of 100-200, depending on season, with respect to $\mathrm{Na}$, even though they have essentially the same abundance in carbonaceous Ivuna (CI) chondrites (Lodders, 2003), which are thought to be closest in composition to interplanetary dust particles (IDPs) (Jessberger et al., 2001). Second, the ratio of $\mathrm{Ca}^{+}$to $\mathrm{Ca}$ is around $10: 1$, whereas the analogous ratios for $\mathrm{Na}$ and $\mathrm{Fe}$ are around 0.2:1 (Plane et al., 2015). Third, 
whereas the $\mathrm{Na}$ and $\mathrm{Fe}$ layers at middle to high latitudes have marked seasonal variations, with a wintertime maximum more than 3 times larger than the summertime minimum, there appears to be much less seasonal variation in the Ca layer (Gerding et al., 2000).

There have been two modelling studies, published nearly 2 decades ago, which attempted to explain these striking differences between $\mathrm{Ca}$ and the other meteoric metals (McNeil et al., 1998; Gerding et al., 2000). In order to account for the low relative abundance of $\mathrm{Ca}$, these studies assumed that $\mathrm{Ca}$ ablates much less efficiently than Na from IDPs, based on a thermodynamic model of high-temperature melts (Fegley and Cameron, 1987). The reaction kinetics of most of the relevant neutral and ion-molecule reactions that $\mathrm{Ca}$-containing species are likely to undergo in the MLT had not yet been studied, and so had to be estimated from the analogous reactions of other metals - whereas the second and third features of the $\mathrm{Ca}$ layer highlighted in the previous paragraph would indicate unexpected differences in chemical behaviour. Although the modelling study of Gerding et al. (2000) achieved reasonable agreement with the annual average $\mathrm{Ca}$ layer measurements reported in the same paper (at Kühlungsborn, Germany, $54^{\circ} \mathrm{N}$ ), the seasonal variation of the layer and the $\mathrm{Ca}^{+} / \mathrm{Ca}$ ratio were not modelled satisfactorily.

Since then, we have carried out a number of kinetic studies of the neutral chemistry of $\mathrm{Ca}$ and its oxides $\left(\mathrm{CaO}, \mathrm{CaO}_{2}\right.$, $\left.\mathrm{CaO}_{3}\right)$, hydroxides $\left(\mathrm{CaOH}\right.$ and $\left.\mathrm{Ca}(\mathrm{OH})_{2}\right)$, oxy-hydroxides $\left(\mathrm{OCaOH}\right.$ and $\left.\mathrm{O}_{2} \mathrm{CaOH}\right)$ and carbonate $\left(\mathrm{CaCO}_{3}\right)$ with atmospherically relevant species such as $\mathrm{O}_{3}, \mathrm{O}, \mathrm{H}, \mathrm{O}_{2}, \mathrm{H}_{2} \mathrm{O}$ and $\mathrm{CO}_{2}$ (Campbell and Plane, 2001; Plane and Rollason, 2001; Broadley and Plane, 2010; Gómez-Martín and Plane, 2017). We have also studied the relevant ion-molecule chemistry of $\mathrm{Ca}^{+}, \mathrm{CaO}^{+}, \mathrm{CaO}_{2}^{+}$and various cluster ions (Broadley et al., 2007, 2008), including the dissociative recombination of $\mathrm{CaO}^{+}$with electrons (Bones et al., 2016a). This chemistry is illustrated in Fig. 1, which uses blue-shaded boxes to indicate ionized Ca-containing species, and green boxes for the neutrals. The ion-molecule chemistry is broadly similar to that of Fe (Plane et al., 2015). However, the neutral chemistry contains two significant features. First is the formation of the relatively stable carbonate, $\mathrm{CaCO}_{3}$. This has been shown experimentally to react very slowly with atomic $\mathrm{O}$, consistent with a large energy barrier that has been calculated theoretically (Broadley and Plane, 2010). In Sect. 2 we discuss further why formation of $\mathrm{CaCO}_{3}$ is most probably a sink for calcium. Second, $\mathrm{CaOH}$ is involved in a holding cycle with $\mathrm{O}_{2} \mathrm{CaOH}$ and $\mathrm{OCaOH}$, which substantially slows down its rate of its conversion back to Ca (Gómez-Martín and Plane, 2017). These two features indicate that atomic Ca may be depleted because of conversion into very stable reservoir species.

In another development, we have recently constructed a Meteoric Ablation Simulator (MASI) to study experimentally the ablation of different metals from meteoritic fragments, under heating conditions that simulate atmospheric

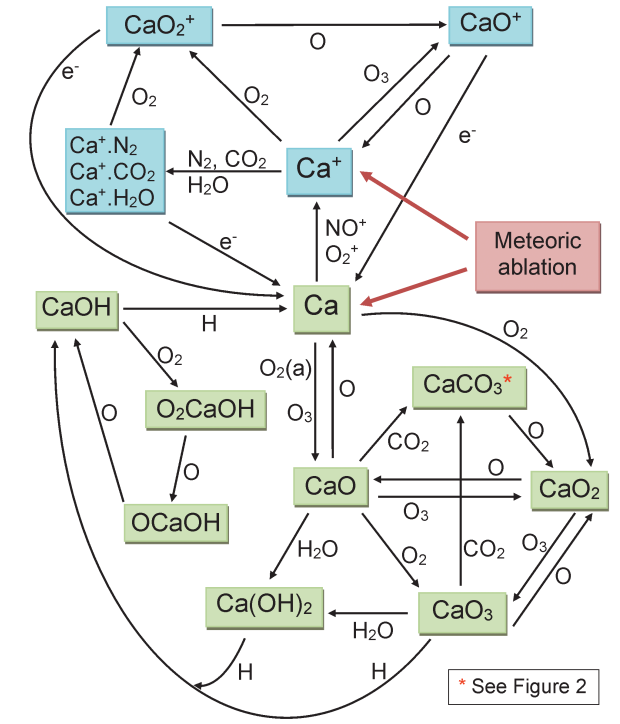

Figure 1. Schematic diagram of the Ca chemistry in WACCM-Ca. Ionized and neutral Ca-containing species are shown in blue and green boxes, respectively.

entry (Bones et al., 2016b). Work with the simulator has confirmed that $\mathrm{Ca}$ does indeed ablate much less efficiently than Na from meteoritic particles, and allowed the Chemical Ablation Model (CABMOD) to be refined and validated (Gómez-Martín et al., 2017a). CABMOD could then be applied to the size and velocity distribution of IDPs entering the Earth's atmosphere - from Jupiter family comets, asteroids, and long-period comets - to determine the meteoric input functions of $\mathrm{Ca}$ and $\mathrm{Na}$ (Carrillo-Sánchez et al., 2016). This showed that the integrated injection rate of $\mathrm{Na}$ was 8.7 times larger than that of $\mathrm{Ca}$, i.e. nearly 1 order of magnitude larger than the CI ratio of the metals.

The objective of the present study is therefore to combine in a global chemistry-climate model the substantial improvement in the database of $\mathrm{Ca}$ reaction kinetics with the experimentally based meteoric input function (MIF) for $\mathrm{Ca}$, and to determine whether the severe depletion of atomic $\mathrm{Ca}$ and the unusually large $\mathrm{Ca}^{+} / \mathrm{Ca}$ ratio can now be explained.

\section{Methods}

\subsection{Ca chemistry}

The rate coefficients for the reactions illustrated in Fig. 1 are listed in Table 1. Most of these have now been measured, as indicated in the footnotes to the table. As mentioned in the Introduction, we have recently carried out an experimental study of $\mathrm{CaOH}$ associating with $\mathrm{O}_{2}$, followed by sequential reactions with atomic $\mathrm{O}$ to yield $\mathrm{CaOH}$ via $\mathrm{O}_{2} \mathrm{CaOH}$ and OCaOH (Gómez-Martín and Plane, 2017). Here we use electronic structure calculations at the B3LYP/6-311+g(2d,p) 
Table 1. Gas-phase neutral and ion-molecule reactions of Ca species.

\begin{tabular}{|c|c|c|}
\hline Number & Reaction & Rate coefficient $^{\mathrm{a}}$ \\
\hline \multicolumn{3}{|c|}{ Neutral chemistry } \\
\hline $\mathrm{R} 1$ & $\mathrm{Ca}+\mathrm{O}_{3} \rightarrow \mathrm{CaO}+\mathrm{O}_{2}$ & $8.2 \times 10^{-10} \exp (-192 / T)^{b}$ \\
\hline $\mathrm{R} 2$ & $\mathrm{Ca}+\mathrm{O}_{2}\left(a^{1} \Delta_{g}\right) \rightarrow \mathrm{CaO}+\mathrm{O}$ & $2.7 \times 10^{-12 \mathrm{c}}$ \\
\hline $\mathrm{R} 3$ & $\mathrm{CaO}+\mathrm{O} \rightarrow \mathrm{Ca}+\mathrm{O}_{2}$ & $1.1 e \times 10^{-9} \exp (-421 / T)^{\mathrm{d}}$ \\
\hline R4 & $\mathrm{CaO}+\mathrm{O}_{3} \rightarrow \mathrm{CaO}_{2}+\mathrm{O}_{2}$ & $5.7 \times 10^{-10} \exp (-267 / T)^{\mathrm{e}}$ \\
\hline R5 & $\mathrm{Ca}+\mathrm{O}_{2}(+\mathrm{M}) \rightarrow \mathrm{CaO}_{2}$ & $1.2 \times 10^{-30}(T / 200)^{3.65 \mathrm{f}}$ \\
\hline R6 & $\mathrm{CaO}_{2}+\mathrm{O} \rightarrow \mathrm{CaO}+\mathrm{O}_{2}$ & $4.4 \times 10^{-11} \exp (-202 / T)^{\mathrm{d}}$ \\
\hline R7 & $\mathrm{CaO}_{2}+\mathrm{O}_{3} \rightarrow \mathrm{CaO}_{3}+\mathrm{O}_{2}$ & $1 \times 10^{-10}(T / 200)^{0.5 \mathrm{~g}}$ \\
\hline R8 & $\mathrm{CaO}_{2}+\mathrm{H} \rightarrow \mathrm{CaOH}+\mathrm{O}$ & $1.2 \times 10^{-11 \mathrm{~d}}$ \\
\hline R9 & $\mathrm{CaO}+\mathrm{H}_{2} \mathrm{O}(+\mathrm{M}) \rightarrow \mathrm{Ca}(\mathrm{OH})_{2}$ & $7.3 \times 10^{-25}(T / 200)^{-2.12 \mathrm{e}}$ \\
\hline R10 & $\mathrm{CaO}+\mathrm{O}_{2}(+\mathrm{M}) \rightarrow \mathrm{CaO}_{3}$ & $6.4 \times 10^{-28}(T / 200)^{-0.358 \mathrm{e}}$ \\
\hline R11 & $\mathrm{CaO}+\mathrm{CO}_{2}(+\mathrm{M}) \rightarrow \mathrm{CaCO}_{3}$ & $2.9 \times 10^{-27}(T / 200)^{-1.07 \mathrm{e}}$ \\
\hline $\mathrm{R} 12$ & $\mathrm{CaO}_{3}+\mathrm{H}_{2} \mathrm{O} \rightarrow \mathrm{Ca}(\mathrm{OH})_{2}+\mathrm{O}_{2}$ & $5 \times 10^{-12 \mathrm{~g}}$ \\
\hline R13 & $\mathrm{CaO}_{3}+\mathrm{CO}_{2} \rightarrow \mathrm{CaCO}_{3}+\mathrm{O}_{2}$ & $5 \times 10^{-12} \mathrm{~g}$ \\
\hline R14 & $\mathrm{CaO}_{3}+\mathrm{O} \rightarrow \mathrm{CaO}_{2}+\mathrm{O}_{2}$ & $2 \times 10^{-11 \mathrm{~g}}$ \\
\hline $\mathrm{R} 15$ & $\mathrm{CaO}_{3}+\mathrm{H} \rightarrow \mathrm{CaOH}+\mathrm{O}_{2}$ & $1.7 \times 10^{-11 \mathrm{~d}}$ \\
\hline $\mathrm{R} 16$ & $\mathrm{CaCO}_{3}+\mathrm{O} \rightarrow \mathrm{CaO}_{2}+\mathrm{CO}_{2}$ & $4.0 \times 10^{-12} \exp (-4689 / T)^{\mathrm{d}, \mathrm{h}}$ \\
\hline R17 & $\mathrm{Ca}(\mathrm{OH})_{2}+\mathrm{H} \rightarrow \mathrm{CaOH}+\mathrm{H}_{2} \mathrm{O}$ & $1 \times 10^{-11 \mathrm{~d}}$ \\
\hline $\mathrm{R} 18$ & $\mathrm{CaOH}+\mathrm{H} \rightarrow \mathrm{Ca}+\mathrm{H}_{2} \mathrm{O}$ & $1.0 \times 10^{-10 i}$ \\
\hline R19 & $\mathrm{CaOH}+\mathrm{O}_{2}(+\mathrm{M}) \rightarrow \mathrm{O}_{2} \mathrm{CaOH}$ & $\begin{array}{l}k_{0}=8.9 \times 10^{-26}(300 / T)^{4.99 \mathrm{i}} \\
k_{\infty}=1.5 \times 10^{-10}(T / 300)^{0.167} \\
F_{\mathrm{c}}=0.136\end{array}$ \\
\hline $\mathrm{R} 20$ & $\mathrm{O}_{2} \mathrm{CaOH}+\mathrm{O} \rightarrow \mathrm{OCaOH}+\mathrm{O}_{2}$ & $2 \times 10^{-10 i}$ \\
\hline $\mathrm{R} 21$ & $\mathrm{OCaOH}+\mathrm{O} \rightarrow \mathrm{CaOH}+\mathrm{O}_{2}$ & $1.5 \times 10^{-10 \mathrm{i}}$ \\
\hline $\mathrm{R} 22$ & Polymerization of $\mathrm{CaOH}, \mathrm{Ca}(\mathrm{OH})_{2}, \mathrm{OCaO}_{2} \mathrm{H}, \mathrm{OCaOH}, \mathrm{CaCO}_{3}$ & $9 \times 10^{-8 j}$ \\
\hline
\end{tabular}

Ion-molecule chemistry

\begin{tabular}{lll}
\hline $\mathrm{R} 23$ & $\mathrm{Ca}+\mathrm{O}_{2}^{+} \rightarrow \mathrm{Ca}^{+}+\mathrm{O}_{2}$ & $1.8 \times 10^{-9 \mathrm{k}}$ \\
$\mathrm{R} 24$ & $\mathrm{Ca}+\mathrm{NO}^{+} \rightarrow \mathrm{Ca}^{+}+\mathrm{NO}$ & $4.0 \times 10^{-9 \mathrm{k}, 1}$ \\
$\mathrm{R} 25$ & $\mathrm{Ca}^{+}+\mathrm{O}_{3} \rightarrow \mathrm{CaO}^{+}+\mathrm{O}_{2}$ & $3.9 \times 10^{-10 \mathrm{~m}, \mathrm{n}}$ \\
$\mathrm{R} 26$ & $\mathrm{CaO}^{+}+\mathrm{O} \rightarrow \mathrm{Ca}^{+}+\mathrm{O}_{2}$ & $4.2 \times 10^{-11 \mathrm{o}}$ \\
$\mathrm{R} 27$ & $\mathrm{Ca}^{+}+\mathrm{O}_{2}(+\mathrm{M}) \rightarrow \mathrm{CaO}_{2}^{+}$ & $4.2 \times 10^{-29}(T / 200)^{-2.37 \mathrm{~m}}$ \\
$\mathrm{R} 28$ & $\mathrm{CaO}_{2}^{+}+\mathrm{O} \rightarrow \mathrm{CaO}^{+}+\mathrm{O}_{2}$ & $1.0 \times 10^{-10 \mathrm{o}}$ \\
$\mathrm{R} 29$ & $\mathrm{Ca}^{+}+\mathrm{N}_{2}+\mathrm{M} \rightarrow \mathrm{Ca} \cdot \mathrm{N}_{2}^{+}+\mathrm{M}$ & $2.3 \times 10^{-30}(T / 200)^{-2.49 \mathrm{~m}}$ \\
$\mathrm{R} 30$ & $\mathrm{Ca}^{+}+\mathrm{CO}_{2}(+\mathrm{M}) \rightarrow \mathrm{Ca}^{+} \cdot \mathrm{CO}_{2}$ & $4.3 \times 10^{-29}(T / 200)^{-3.09 \mathrm{~m}}$ \\
$\mathrm{R} 31$ & $\mathrm{Ca}^{+}+\mathrm{H}_{2} \mathrm{O}(+\mathrm{M}) \rightarrow \mathrm{Ca}^{+} \cdot \mathrm{H}_{2} \mathrm{O}$ & $1.2 \times 10^{-28}(T / 200)^{-2.12 \mathrm{~m}}$ \\
$\mathrm{R} 32$ & $\mathrm{Ca}^{-} \mathrm{N}_{2}^{+}+\mathrm{O}_{2} \rightarrow \mathrm{CaO}_{2}^{+}+\mathrm{N}_{2}$ & $3 \times 10^{-10} \mathrm{o}$ \\
$\mathrm{R} 33$ & $\mathrm{Ca}^{+} \cdot \mathrm{CO}_{2}+\mathrm{O}_{2} \rightarrow \mathrm{CaO}_{2}^{+}+\mathrm{CO}_{2}$ & $1.2 \times 10^{-10} \mathrm{o}$ \\
$\mathrm{R} 34$ & $\mathrm{Ca}^{+} \cdot \mathrm{CO}_{2}+\mathrm{H}_{2} \mathrm{O} \rightarrow \mathrm{Ca}^{+} \cdot \mathrm{H}_{2} \mathrm{O}+\mathrm{CO}_{2}$ & $1.3 \times 10^{-9} \mathrm{o}$ \\
$\mathrm{R} 35$ & $\mathrm{Ca}^{+} \cdot \mathrm{H}_{2} \mathrm{O}+\mathrm{O}_{2} \rightarrow \mathrm{CaO}_{2}^{+}+\mathrm{H}_{2} \mathrm{O}$ & $4.0 \times 10^{-10} \mathrm{o}$ \\
$\mathrm{R} 36$ & $\mathrm{Ca}^{+}+e^{-} \rightarrow \mathrm{Ca}+X\left(X=\mathrm{O}_{2}, \mathrm{O}_{2}, \mathrm{~N}_{2}, \mathrm{CO}_{2}, \mathrm{H}_{2} \mathrm{O}\right)$ & $3 \times 10^{-7}(T / 295)^{-1 / 2 \mathrm{p}}$ \\
$\mathrm{R} 37$ & $\mathrm{Ca}+e^{-} \rightarrow \mathrm{Ca}^{+} h v$ & $3.8 \times 10^{-12}(T / 200)^{-0.9} \mathrm{q}$ \\
\hline Photochemical reactions & \\
\hline $\mathrm{R} 38$ & $\mathrm{Ca}+h v \rightarrow \mathrm{Ca}^{+}+e^{-}$ & $5 \times 10^{-5 \mathrm{r}}$ \\
\hline
\end{tabular}

${ }^{a}$ Units: unimolecular, $\mathrm{s}^{-1}$; bimolecular, $\mathrm{cm}^{3}$ molecule ${ }^{-1} \mathrm{~s}^{-1}$; termolecular, $\mathrm{cm}^{6}$ molecule ${ }^{-2} \mathrm{~s}^{-1}$. Rate coefficients are from ${ }^{\mathrm{b}}$ Helmer et al. (1993), ${ }^{c}$ Plane et al. (2012), ${ }^{\mathrm{d}}$ Broadley and Plane (2010), ${ }^{\mathrm{e}}$ Plane and Rollason (2001) and ${ }^{\mathrm{f}}$ Campbell and Plane (2001). ${ }^{\mathrm{g}}$ Estimate. ${ }^{\mathrm{h}}$ Calculated using transition state theory (see the Supplement). ${ }^{\mathrm{i}}$ Gómez-Martín and Plane (2017). ${ }^{\mathrm{j}}$ Fitted sink reaction (see text). ${ }^{\mathrm{k}}$ Rutherford et al. (1972). ${ }^{1}$ In the sensitivity run, reduced to the Langevin capture rate of $2.8 \times 10^{-9} \mathrm{~cm}^{3} \mathrm{~s}^{-1}$ (see text). ${ }^{\mathrm{m}}$ Broadley et al. (2007). ${ }^{\mathrm{n}}$ In the sensitivity run, increased to the Langevin capture rate of $1.1 \times 10^{-9} \mathrm{~cm}^{3} \mathrm{~s}^{-1}$ (see text). ${ }^{\circ}$ Broadley et al. (2008). $\mathrm{P}^{\mathrm{B}}$ Bones et al. (2016a). ${ }^{\mathrm{q}}$ Shull and van Steenberg (1982). ${ }^{\mathrm{r}}$ Calculated from the Ca photo-ionization cross section (McIlrath and Sandeman, 1972; Ahmad et al., 1994). 
level of theory (Frisch et al., 2009) to show that $\mathrm{CaCO}_{3}$ should be involved in an analogous holding cycle, illustrated in Fig. 2a:

$$
\begin{gathered}
\mathrm{CaCO}_{3}+\mathrm{O}_{2}(+\mathrm{M}) \rightarrow \mathrm{O}_{2} \mathrm{CaCO}_{3}, \\
\Delta H^{o}=-89 \mathrm{~kJ} \mathrm{~mol}^{-1}, \\
\mathrm{O}_{2} \mathrm{CaCO}_{3}+\mathrm{O} \rightarrow \mathrm{OCaCO}_{3}+\mathrm{O}_{2}, \\
\Delta H^{o}=-110 \mathrm{~kJ} \mathrm{~mol}^{-1}, \\
\mathrm{OCaCO}_{3}+\mathrm{O} \rightarrow \mathrm{CaCO}_{3}+\mathrm{O}_{2}, \\
\Delta H^{o}=-311 \mathrm{~kJ} \mathrm{~mol}^{-1}
\end{gathered}
$$

Reaction (R40) should be very fast in the MLT, because $\mathrm{O}_{2}$ is a major atmospheric constituent and the reaction has a large calculated rate coefficient of $k_{40}(200 \mathrm{~K})=$ $4.0 \times 10^{-26}(T / 200)^{-3.85} \mathrm{~cm}^{6}$ molecule ${ }^{-2} \mathrm{~s}^{-1}$ (see the Supplement). Reaction (R41) involves reaction with atomic $\mathrm{O}$, which is another major species above the "atomic O shelf" around $82 \mathrm{~km}$ (Plane et al., 2015). As shown in Fig. 2b, this reaction can produce $\mathrm{OCaCO}_{3}$ (Reaction R41a) on a triplet electronic surface via transition state TS1 or on a singlet surface via TS2 (molecular parameters are listed in the Supplement). The highly exothermic Reaction (R42) involving atomic $\mathrm{O}$ then reduces $\mathrm{OCaCO}_{3}$ back to $\mathrm{CaCO}_{3}$ to complete the cycle.

However, Reaction (R41) can also produce $\mathrm{O}_{2} \mathrm{CaO}_{2}$ on the singlet surface via TS3.

$$
\begin{gathered}
\mathrm{O}_{2} \mathrm{CaCO}_{3}+\mathrm{O} \rightarrow \mathrm{O}_{2} \mathrm{CaO}_{2}+\mathrm{CO}_{2}, \\
\Delta H^{o}=-65 \mathrm{~kJ} \mathrm{~mol}^{-1},
\end{gathered}
$$

which would be followed by $\mathrm{O}_{2} \mathrm{CaO}_{2}$ reacting with a second O:

$$
\begin{gathered}
\mathrm{O}_{2} \mathrm{CaO}_{2}+\mathrm{O} \rightarrow \mathrm{CaO}_{3}+\mathrm{O}_{2}, \\
\Delta H^{o}=-311 \mathrm{~kJ} \mathrm{~mol}^{-1} .
\end{gathered}
$$

As shown in Fig. $1, \mathrm{CaO}_{3}$ is chemically labile, with pathways to other oxides and hydroxides, and so if Reaction (R41b) is competitive with Reaction (R41a) then $\mathrm{CaCO}_{3}$ (and $\mathrm{O}_{2} \mathrm{CaCO}_{3}$ ) would be a less stable calcium reservoir. We therefore performed a Rice-Ramsperger-Kassel-Markus (RRKM) calculation on the reaction $\mathrm{O}_{2} \mathrm{CaCO}_{3}+\mathrm{O}$ using the Master Equation Solver for Multi-Energy well Reactions (MESMER) program (Glowacki et al., 2012; Robertson et al., 2012). The molecular parameters are listed in Table S3 in the Supplement. The MESMER calculation shows that at $T=200 \mathrm{~K}$ and $p=10^{-5}$ bar (typical conditions of the $80-85 \mathrm{~km}$ region), $99.6 \%$ of the reaction product is $\mathrm{OCaCO}_{3}$ (produced in essentially equal amounts on the triplet and singlet surfaces), and $0.4 \%$ is $\mathrm{O}_{2} \mathrm{CaO}_{2}$. Thus the $\mathrm{CaCO}_{3} \rightarrow \mathrm{O}_{2} \mathrm{CaCO}_{3} \rightarrow \mathrm{OCaCO}_{3} \rightarrow \mathrm{CaCO}_{3}$ cycle should sequester most of the calcium below the peak of the atomic $\mathrm{Ca}$ layer. The rate coefficient $k_{2}$ should also be around
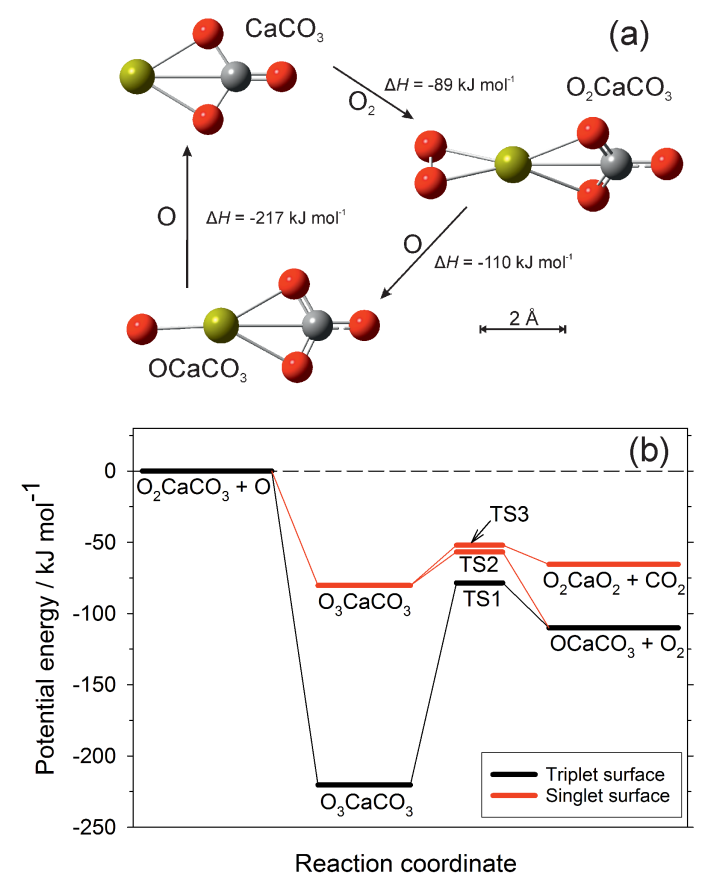

Figure 2. (a) $\mathrm{The}^{\mathrm{CaCO}_{3}}$ holding cycle, analogous to that of $\mathrm{CaOH}$ (Gómez-Martín and Plane, 2017). Colour scheme: Ca (yellow), C (grey), $\mathrm{O}$ (red). The reaction enthalpies (at $0 \mathrm{~K}$ ) for each step were calculated at the B3LYP/6-311+g(2d,p) level of theory (Frisch et al., 2009). (b) Potential energy surface for the reaction between $\mathrm{O}_{2} \mathrm{CaCO}_{3}$ and $\mathrm{O}$, calculated at the B3LYP/6-311+g(2d,p) level of theory. Zero-point energies are included in the energies of the stationary points. The quintet surface for this reaction is non-reactive.

$2 \times 10^{-10} \mathrm{~cm}^{3}$ molecule $\mathrm{s}^{-1} \mathrm{~s}^{-1}$, essentially equal to the capture rate because the barriers on the potential energy surfaces are submerged below the entrance channel (Fig. 2b). Because the $e$-folding lifetime of $\mathrm{CaCO}_{3}$ against recombination with $\mathrm{O}_{2}$ is only $\sim 10 \mathrm{~ms}$ at a height of $82 \mathrm{~km}$, and the $e$-folding time of Reaction (R42) should be around $0.25 \mathrm{~s}, \sim 96 \%$ of the $\mathrm{CaCO}_{3}$ will be clustered to $\mathrm{O}_{2}$.

Reaction (R22) in Table 1 is a polymerization reaction, which describes the permanent loss of the neutral reservoir species to form meteoric smoke particles. We have used this type of reaction previously for modelling the $\mathrm{Na}$ and Fe layers (Feng et al., 2013; Marsh et al., 2013a). Here, the rate coefficient $k_{22}$ is set to $9 \times 10^{-8} \mathrm{~cm}^{3} \mathrm{~s}^{-1}$. This is around 100 times larger than a typical dipole-dipole capture rate for these metallic molecules, which often have very large dipole moments (e.g. the calculated $\mu_{D}$ for $\mathrm{CaCO}_{3}$ is 13.5 D; Broadley and Plane, 2010). The reason for increasing the rate coefficient by a factor of $\sim 100$ is that the $\mathrm{Ca}$ reservoir species can also polymerize with other (i.e. non-Ca containing) meteoric molecules (e.g. $\mathrm{NaHCO}_{3}, \mathrm{FeOH}$, and $\left.\mathrm{Mg}(\mathrm{OH})_{2}\right)$, and the dimerization rate coefficient needs to be increased to account for this since $\mathrm{Ca}$ ablates in a large excess of these other metals: the elemental ablation ratio of $\mathrm{Ca}$ 
atoms to the sum of $\mathrm{Na}, \mathrm{Fe}, \mathrm{Mg}, \mathrm{Si}, \mathrm{Al}$ and $\mathrm{K}$ atoms is 0.01 (Carrillo-Sánchez et al., 2016). A similar procedure was used to model the $\mathrm{K}$ layer, where the dimerization rate coefficient of $\mathrm{KHCO}_{3}$ was increased by a factor of 270 (Plane et al., 2014).

The photo-ionization rate of $\mathrm{Ca}$ (Reaction R38 in Table 1) in the MLT was first estimated by Swider (1969). Using the more recently measured cross section of $2.0 \mathrm{Mb}$ near the threshold at $202.9 \mathrm{~nm}$ (Ahmad et al., 1994), and $52 \mathrm{Mb}$ at the $188.6 \mathrm{~nm}$ peak in the photo-ionization spectrum (McIlrath and Sandeman, 1972), we obtain essentially the same photoionization rate as Swider of $5 \times 10^{-5} \mathrm{~s}^{-1}$. Note that $\mathrm{Ca}$ has an unusually fast photo-ionization rate, which is 2.5 times faster than $\mathrm{Na}$ and 100 times faster than Fe (Plane et al., 2015).

\subsection{Whole-atmosphere model of Ca}

The 3-D global model of meteoric calcium was constructed by adding the Ca chemistry described in Sect. 2.1 into the Whole Atmosphere Community Climate Model (WACCM). WACCM uses the framework from the fully coupled global climate model Community Earth System Model (CESM) (Hurrell et al., 2013) and is a comprehensive numerical model extending vertically from the Earth's surface to the lower thermosphere $(\sim 140 \mathrm{~km})$ (e.g. Marsh et al., 2013b). For the present study we used a specific dynamics (SD) version of WACCM discussed in Feng et al. (2017), which is nudged with NASA's Modern-Era Retrospective Analysis for Research and Applications (MERRA) (Lamarque et al., 2012) below $60 \mathrm{~km}$, and has the fully interactive chemistry described in Marsh et al. (2013b). The horizontal resolution is $1.9^{\circ}$ latitude $\times 2.5^{\circ}$ longitude, with 88 vertical model layers giving a height resolution of $\sim 3.5 \mathrm{~km}$ in the MLT. In order to compare the Ca with the Na layer, a WACCM-Na simulation was also performed, where the Na chemistry was updated from Marsh et al. (2013a) with the results of two recent kinetic studies from our laboratory (Gómez-Martín et al., 2016, 2017b).

The injection profiles of $\mathrm{Ca}$ and $\mathrm{Na}$ used in WACCM-Ca and WACCM-Na are illustrated in Fig. 3. These meteoric input functions (MIFs) were determined for the input of cosmic dust particles from three sources: Jupiter family comets, the asteroid belt, and long-period comets (i.e. Halley-type and Oort-cloud comets) (Carrillo-Sánchez et al., 2016). The elemental ablation rates of individual particles, selected using a Monte Carlo procedure from the dust size and velocity distributions predicted by an astronomical model (Nesvorný et al., 2011), were processed through CABMOD (Vondrak et al., 2008). These rates were then summed over the size and velocity distributions to produce the MIF (Carrillo-Sánchez et al., 2016).

It has become apparent in the past few years that global models such as WACCM underestimate the transport of minor species through the MLT. This appears to be because the chemical and dynamical transport caused by dissipating at-

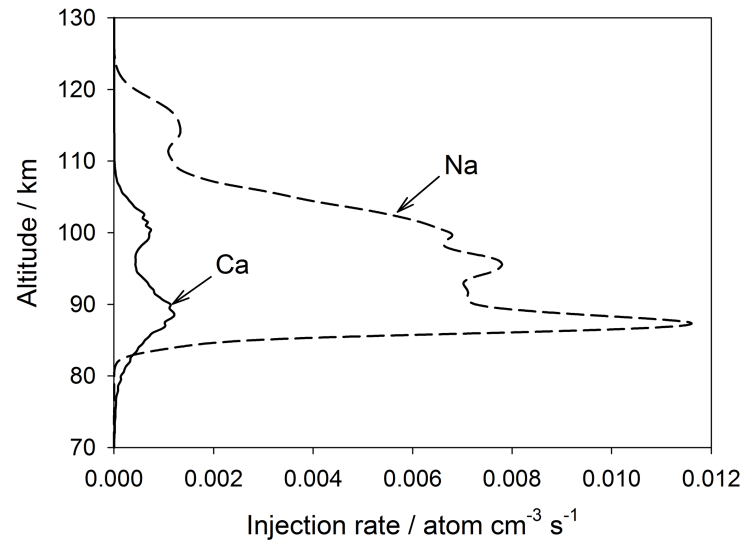

Figure 3. Global annual mean injection rate profiles of $\mathrm{Ca}$ and $\mathrm{Na}$ resulting from meteoric ablation, used in WACCM. Note that these injection rates have been reduced by a factor of 5 from those determined by Carrillo-Sanchez et al. (2016).

mospheric gravity waves can exceed transport driven along mixing ratio gradients by the turbulent eddy diffusion produced by breaking waves (Gardner et al., 2016). Short wavelength waves are not resolved within the coarse horizontal grid scales of models such as WACCM $(\sim 200 \mathrm{~km}$ resolution), so that much of the wave spectrum causing dynamical or chemical transport is not captured (in contrast, eddy diffusion caused by the breaking of sub-grid-scale waves is parameterized). In the absence of these additional vertical transport components, the MIF needs to be reduced in order for the model to produce the observed metal density. In the case of the Na MIF from Carrillo-Sánchez et al. (2016), a reduction by a factor of 5 produces good agreement with observations (see Sect. 3). Because a primary aim of this study is a comparison between $\mathrm{Ca}$ and $\mathrm{Na}$, the $\mathrm{Ca}$ MIF was reduced by the same factor. These reduced MIFs are plotted in Fig. 3. The seasonal variation of these MIFs with latitude (Fig. S2) was derived by scaling to the variation of the $\mathrm{Na}$ and Fe MIFs determined previously using an astronomical dust model (Marsh et al., 2013a; Feng et al., 2013).

Three model simulations were performed. The first run was WACCM-Ca from 1996 to early 2000 (termed the standard run), covering the period when the $\mathrm{Ca}$ and $\mathrm{Ca}^{+}$lidar measurements were made at Kühlungsborn, Germany $\left(54.1^{\circ} \mathrm{N}, 11.7^{\circ} \mathrm{E}\right)$ (Gerding et al., 2000). The second model run was WACCM-Ca and WACCM-Na from 2004 to 2014, to obtain a 10-year climatology which also covers the period when lidar measurements were made at Arecibo, Puerto Rico $\left(18^{\circ} \mathrm{N}, 293^{\circ} \mathrm{E}\right)$ (Raizada et al., 2011). The third run was a sensitivity experiment, where the rate coefficients $k_{24}$ and $k_{25}$ were changed from their experimental values to their ionmolecule capture rate coefficients, calculated using Langevin theory (Smith, 1980) (see footnote to Table 1). The reason for doing this is discussed in Sect. 3. The model outputs for the lidar stations at Kühlungsborn and Arecibo, as well as 
the rocket launching sites at Kiruna, Sweden $\left(68^{\circ} \mathrm{N}, 22^{\circ} \mathrm{E}\right)$; Red Lake, Canada $\left(51^{\circ} \mathrm{N}, 267^{\circ} \mathrm{E}\right)$; and Wallops, Virginia, USA $\left(38^{\circ} \mathrm{N}, 285^{\circ} \mathrm{E}\right)$, were sampled every $30 \mathrm{~min}$ as in Feng et al. (2013).

\subsection{Observational data}

The lidar soundings at Kühlungsborn $\left(54^{\circ} \mathrm{N}\right)$ were carried out with the double resonance lidar system described by Alpers et al. (1996) and Gerding et al. (2000). With this lidar system two dye lasers are operated in parallel, allowing for simultaneous, common-volume soundings of $\mathrm{Ca}$ and $\mathrm{Ca}^{+}$(or $\mathrm{Ca} / \mathrm{Na}$ or $\mathrm{Ca} / \mathrm{Fe}$, depending on configuration). For this study we extended the data set described by Gerding et al. (2000). Overall, 131 nights of $\mathrm{Ca}$ observations were recorded between December 1996 and January 2000. Many of these show prominent sporadic layers (e.g. Gerding et al., 2001). These nights are excluded here, because they are strongly related to sporadic electron layers and other parameters that are not currently simulated in WACCM. A total of 75 nights of observations remain (i.e. 42 nights of observations in 1997, 24 nights in 1998, 7 nights in 1999 and 2 nights in January 2000), each covering between 0.5 and $10.3 \mathrm{~h}$. In order to compare the model most directly with the observations when determining the seasonal variation of $\mathrm{Ca}$, the model output was sampled at the times of the individual Ca measurements. The second dye laser was partly operated at the $\mathrm{Ca}^{+}$resonance transition. Here, 72 nights of observations are available. For $\mathrm{Ca}^{+}$it is not possible to distinguish between nights with and without sporadic layers, so all data are used.

The lidar system at the Arecibo Observatory $\left(18^{\circ} \mathrm{N}\right)$ employed for measurements of neutral $\mathrm{Ca}$ at $423 \mathrm{~nm}$ has been described previously (Raizada et al., 2011, 2012). Nd:YAGpumped dye laser output at $701 \mathrm{~nm}$ is mixed with the YAG fundamental at $1064 \mathrm{~nm}$ to produce $423 \mathrm{~nm}$ light by sum frequency. The data presented in this work were collected during 2002-2003 (17 nights) and 2008-2010 (39 nights), giving a total of 56 nights. To eliminate the influence of strong sporadic layers, the nightly average Ca profile was fitted with a Gaussian function, which was then integrated to yield the average column abundance. The monthly mean abundance is used here.

For comparison with the $\mathrm{Na}$ layer at the respective latitudes of 54 and $38^{\circ} \mathrm{N}$ we use observations from the Osiris spectrometer on the ODIN satellite (Fan et al., 2007; Dawkins et al., 2015). While these data are obtained at around 06:00 and 18:00 LT (local time) in the daytime, the $\mathrm{Na}$ layer column abundance exhibits a very small diurnal variation (Clemesha et al., 1982) and so these data are appropriate for comparison with the nighttime $\mathrm{Ca}$ lidar measurements.

Nine vertical profiles of $\mathrm{Ca}^{+}(\mathrm{m} / z=40)$ and $\mathrm{Na}^{+}(\mathrm{m} / z=$ 23) measured by rocket-borne mass spectrometry are also included. Two of these rockets were launched from Wallops Islands $\left(37.8^{\circ} \mathrm{N}, \mathrm{USA}\right)$ at $11: 58 \mathrm{LT}$ on 12 August 1976 and
14:03 LT on 1 January 1977 (payloads 18.1006, Herrmann et al., 1978, and 18.1008, Meister et al., 1978, respectively). Two further launches took place at Red Lake $\left(50.9^{\circ} \mathrm{N}\right.$, Canada), at 11:52 LT on 24 February 1979 and 11:55 LT on 26 February 1979 (payloads 18.020 and 18.021; Kopp and Herrmann, 1984; Kopp, 1997). The rest were launched from Kiruna $\left(67.8^{\circ} \mathrm{N}\right.$, Sweden) at 01:32 LT on 30 July 1978 and 01:38 LT on 13 August 1978 (payloads S26/1 and S26/2; Kopp et al., 1985b), at 04:50 LT on 16 November 1980 and 01:44 LT on 30 November 1980 (payloads 33.010 and 33.009; Kopp et al., 1985a), and at 01:32 LT on 3 August 1982 (payload S37/P; Kopp et al., 1984).

The $m / z=40$ profile consist primarily of $\mathrm{Ca}^{+}$(Zbinden et al., 1975). Based on recent detailed modelling of $\mathrm{Na}$ and $\mathrm{Mg}$ chemistry (Plane and Whalley, 2012; Marsh et al., 2013b), significant contributions from $\mathrm{NaOH}^{+}$and $\mathrm{MgO}^{+}$can be ruled out. The 42/40 and 44/40 signal ratios in sporadic E layers have been found to be close to the ${ }^{44} \mathrm{Ca} /{ }^{40} \mathrm{Ca}$ and ${ }^{42} \mathrm{Ca} /{ }^{40} \mathrm{Ca}$ terrestrial isotopic ratios (Herrmann et al., 1978).

\section{Results and discussion}

\subsection{Annual mean profiles of Ca species}

Figure 4a compares the annual mean $\mathrm{Ca}$ and $\mathrm{Ca}^{+}$vertical profiles simulated by WACCM-Ca with the annual mean lidar measurements at Kühlungsborn, and two rocket measurements of $\mathrm{Ca}^{+}$over Red Lake, Canada, which is at a similar latitude. Note that the model output was sampled to the times when lidar data were available, over the period between 1997 and 2000. The modelled and measured Ca peak height, peak density, and top and model scale heights of the $\mathrm{Ca}$ layer all agree within their standard deviations. Observations show that the $\mathrm{Ca}^{+}$layer is much more variable than the Ca layer (Gerding et al., 2000; Granier et al., 1989). Although there is reasonable agreement in the general shape of the $\mathrm{Ca}^{+}$layer, and the model captures the $\mathrm{Ca}^{+}$ion density at certain heights measured both by the lidar and the two rocket flights, overall the model appears to over-predict the $\mathrm{Ca}^{+}$density. This is a problem that we have encountered previously with WACCM modelling of both $\mathrm{Na}^{+}$(Marsh et al., 2013a) and $\mathrm{Fe}^{+}$(Feng et al., 2013), which we have attributed to the absence of electro-dynamical transport of these metallic ions in WACCM. This point is discussed further below.

Figure $4 \mathrm{~b}$ illustrates vertical profiles of the neutral $\mathrm{Ca}$ species. The oxides $\mathrm{CaO}, \mathrm{CaO}_{2}$ and $\mathrm{CaO}_{3}$ have relatively minor concentrations because they are destroyed by reaction with atomic $\mathrm{O}$ (Table 1). The hydroxides $\mathrm{Ca}(\mathrm{OH})_{2}, \mathrm{O}_{2} \mathrm{CaOH}$ and $\mathrm{OCaOH}$ are comparatively abundant because the $\mathrm{H}$ atom concentration is roughly 2 orders of magnitude lower than atomic O (Plane et al., 2015). Below the Ca layer peak $(\sim 90 \mathrm{~km}), \mathrm{CaCO}_{3}$ is the dominant gas-phase Ca species; although note that the line labelled $\mathrm{CaCO}_{3}$ refers to the sum $\mathrm{CaCO}_{3}+\mathrm{O}_{2} \mathrm{CaCO}_{3}+\mathrm{OCaCO}_{3}$, which is mostly $\mathrm{O}_{2} \mathrm{CaCO}_{3}$ 

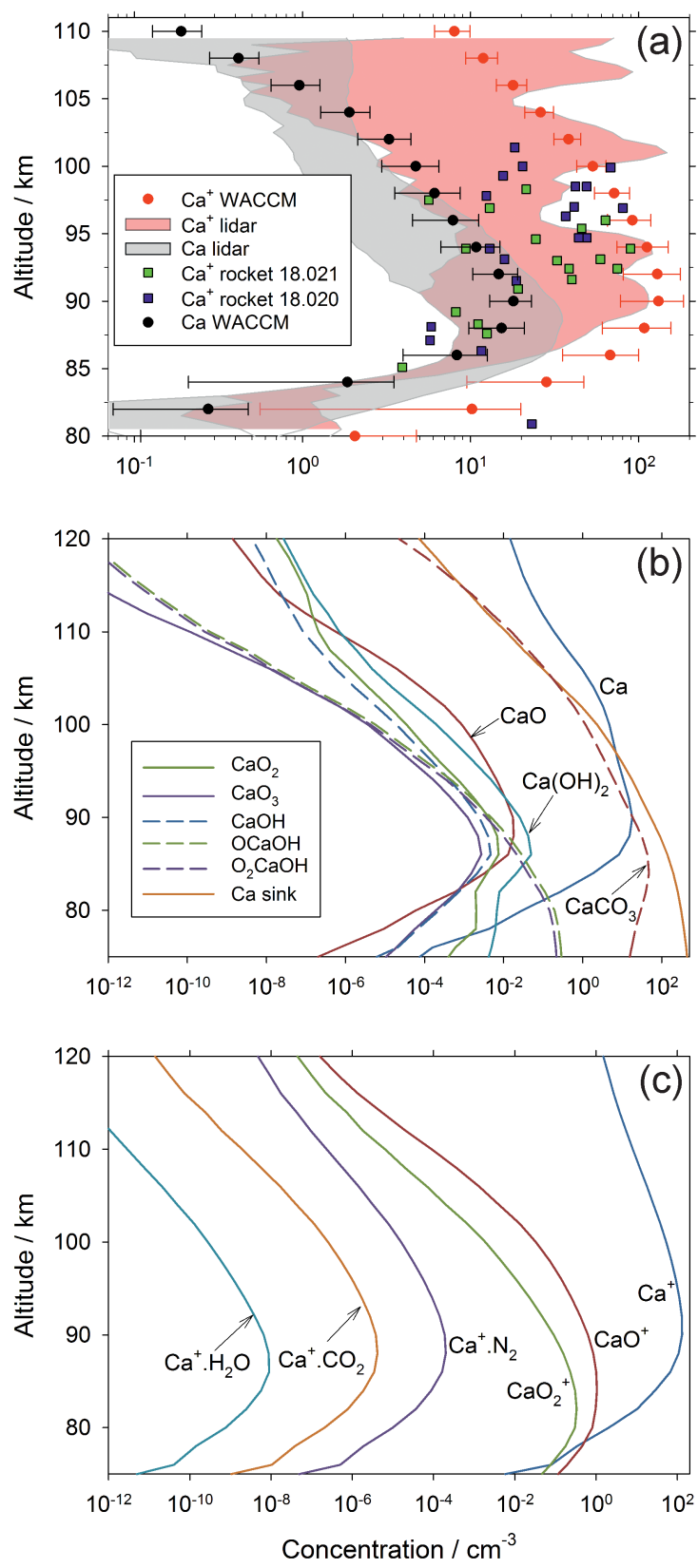

Figure 4. Annual mean concentration profiles of $\mathrm{Ca}$ species over Kühlungsborn $\left(54^{\circ} \mathrm{N}\right)$ : (a) comparison of WACCM-Ca model results (the horizontal error bars indicate 1 standard deviation from the mean) with the lidar measurements of $\mathrm{Ca}$ and $\mathrm{Ca}^{+}$(the shaded areas encompass 1 standard deviation from the mean). Note that the model output was sampled to the lidar data over the same period between 1997 and 2000. Also shown are mass spectrometric measurements of $\mathrm{Ca}^{+}$made by two rockets which were launched from Red Lake (50.9 ${ }^{\circ}$ N, Canada), on 24 February 1979 11:52 LT and 26 February 1979 11:55 LT (payloads 18.020 and 18.021; Kopp and Herrmann, 1984; Kopp, 1997); (b) modelled vertical profiles of neutral Ca species in WACCM-Ca, where " $\mathrm{CaCO}_{3}$ " $=\mathrm{CaCO}_{3}+$ $\mathrm{O}_{2} \mathrm{CaCO}_{3}+\mathrm{OCaCO}_{3}$; (c) modelled vertical profiles of ionic $\mathrm{Ca}$ species in WACCM-Ca. below $90 \mathrm{~km}$, as discussed in Sect. 2.1. Importantly, because of the $\mathrm{CaOH}$ and $\mathrm{CaCO}_{3}$ holding cycles, the dimerization of molecular species is much more important than for other meteoric metals such as Fe (Feng et al., 2013) and $\mathrm{Na}$ (Marsh et al., 2013a). This is why the profile of the Ca sink (representing polymerized $\mathrm{Ca}$ molecules) is the most abundant form of the metal below $97 \mathrm{~km}$. The permanent removal of $\mathrm{Ca}$ into these embryonic particles, and the relatively large concentrations of $\mathrm{Ca}$ species in the $\mathrm{CaOH}$ and $\mathrm{CaCO}_{3}$ holding cycles, thus explains the very low abundance of neutral $\mathrm{Ca}$ atoms.

Figure $4 \mathrm{c}$ illustrates the vertical profiles of the ionized $\mathrm{Ca}$ species. $\mathrm{Ca}^{+}$is the dominant species above $80 \mathrm{~km}$, followed by $\mathrm{CaO}^{+}$and $\mathrm{CaO}_{2}^{+}$. This picture is quite similar to that of $\mathrm{Fe}^{+}$and its oxide ions (Feng et al., 2013). Oxidation of $\mathrm{Ca}^{+}$ by $\mathrm{O}_{3}$ is the dominant reaction above $80 \mathrm{~km}$ (Broadley et al., 2007), because it is a bimolecular reaction in contrast to the third-order association reactions where $\mathrm{Ca}^{+}$clusters with $\mathrm{O}_{2}$, $\mathrm{N}_{2}$ etc. (Table 1). These association reactions are relatively slow at the low pressures in the MLT.

\subsection{Seasonal variation of the Ca layer profile}

Figure 5 displays altitude versus month plots of the Ca layer vertical profile at Kühlungsborn $\left(54^{\circ} \mathrm{N}\right)$. Figure 5 a shows the lidar measurements and Fig. 5b is the standard WACCM-Ca run described in Sect. 2.2. Comparison of these plots, which have the same contour colour scale, shows that the model simulates successfully the height and width of the layer, as well as the minimum in springtime and the broad maximum during the second half of the year. The reason for this unusual seasonal variation is that the $\mathrm{Ca}$ layer abundance tends to follow the seasonal variation of the Ca MIF, which peaks in autumn and has a minimum in spring (Fig. S2 in the Supplement). This MIF dependence is not really observed in the $\mathrm{Na}$ and $\mathrm{Fe}$ layers, which have a strong annual variation, with a minimum in summer and maximum in winter (Feng et al., 2013; Marsh et al., 2013a). The reason that the Ca layer is strongly influenced by the MIF is due to the lifetime of $\mathrm{Ca}$ in the layer being short: this can be estimated by dividing the Ca layer column abundance by the integrated Ca MIF, i.e. $2 \times 10^{7} \mathrm{~cm}^{-2} / 420 \mathrm{~cm}^{-2} \mathrm{~s}^{-1}$, which is around 0.6 days. In comparison, the lifetime of $\mathrm{Na}$ atoms is much longer (around 11 days in the current simulation), so that horizontal (particularly meridional) transport washes out the effect of the $\mathrm{Na}$ MIF.

The comparison between Fig. 5a and b shows that the peak $\mathrm{Ca}$ density is underestimated in July and December by around $50 \%$. Considering that the lidar data set is quite sparse (Gerding et al., 2000), perhaps not too much should be read into this. Nevertheless, noting that $\mathrm{Ca}^{+}$ions tend to be overestimated in the model (Fig. 4a), we carried out a sensitivity study to examine the possibility that the rate coefficients which partition calcium between $\mathrm{Ca}$ and $\mathrm{Ca}^{+}$were incorrectly measured. We therefore reduced the rate coefficient $k_{24}$ for the charge-transfer reaction between $\mathrm{NO}^{+}$and 


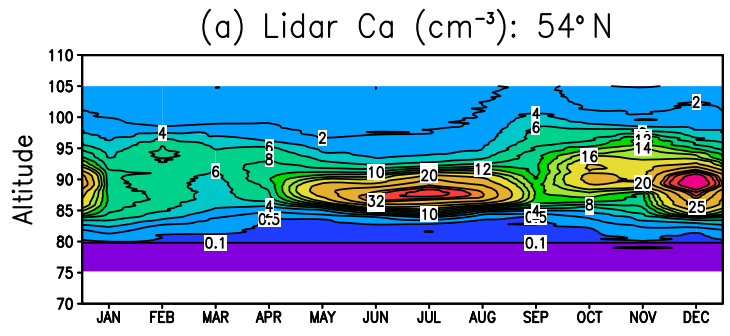

(b) Standard WACCM-Ca $\left(\mathrm{cm}^{-3}\right)$

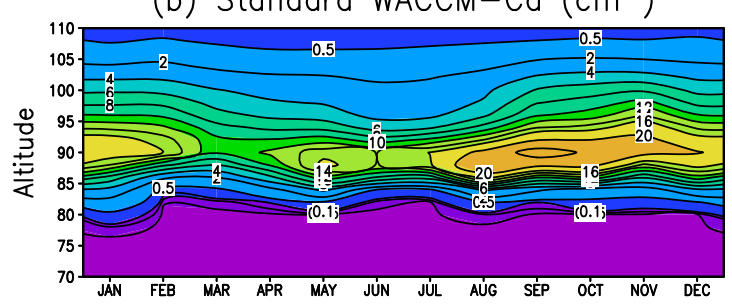

(c) Sensitivity WACCM-Ca $\left(\mathrm{cm}^{-3}\right)$

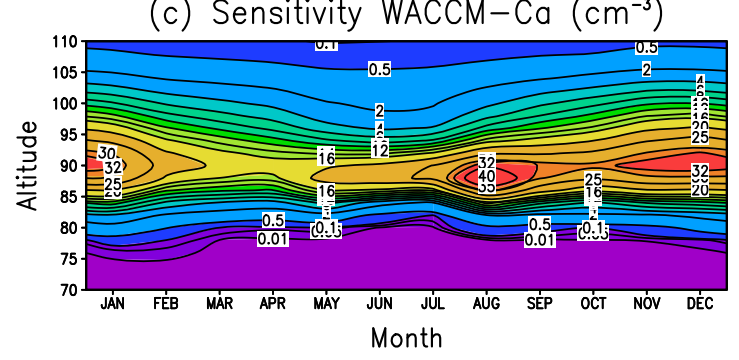

Figure 5. Annual variation of the $\mathrm{Ca}$ layer over Kühlungsborn $\left(54^{\circ} \mathrm{N}\right)$ : (a) lidar measurements, (b) WACCM-Ca standard model run, (c) WACCM-Ca sensitivity run where the rate coefficients for Reactions (R24) and (R25) are set to their respective Langevin capture rates.

Ca, which produces $\mathrm{Ca}^{+}$. The measured rate coefficient of $4 \times 10^{-9} \mathrm{~cm}^{3}$ molecule ${ }^{-1} \mathrm{~s}^{-1}$ (Rutherford et al., 1972) is fast compared with the Langevin capture rate (Smith, 1980) of $2.8 \times 10^{-9} \mathrm{~cm}^{3}$ molecule $\mathrm{s}^{-1}$. The rate coefficient $k_{25}$ for the reaction of $\mathrm{Ca}^{+}$with $\mathrm{O}_{3}$, which is the most important step in converting $\mathrm{Ca}^{+}$to $\mathrm{Ca}$ (see Fig. 1), was also increased from its experimental value of $3.9 \times 10^{-10} \mathrm{~cm}^{3}$ molecule ${ }^{-1} \mathrm{~s}^{-1}$ to the Langevin capture rate of $1.1 \times 10^{-9} \mathrm{~cm}^{3}$ molecule ${ }^{-1} \mathrm{~s}^{-1}$. The result is shown in Fig. 5c. While this does have the desired effect of increasing the Ca peak density to the observed level during July and December, at other times of the year it exceeds the measurements by more than $100 \%$. Furthermore, the column abundance of the layer from the sensitivity simulation is substantially larger than the observations at all times of the year (not shown).

\subsection{Seasonal variation of the $\mathrm{Ca}$ and Na column abundances}

Figure 6a and $\mathrm{b}$ compare the modelled and measured $\mathrm{Ca}$ and $\mathrm{Na}$ column abundances as a function of season at Kühlungsborn $\left(54^{\circ} \mathrm{N}\right)$ and Arecibo $\left(18^{\circ} \mathrm{N}\right)$, respectively. In both
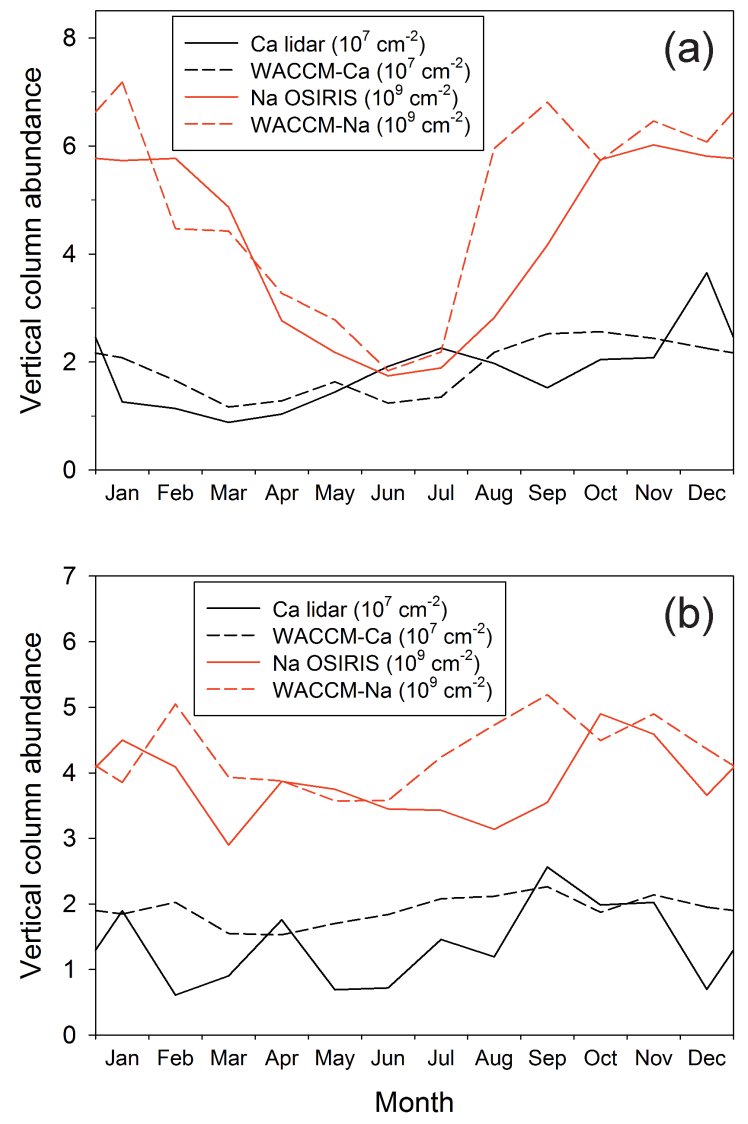

Figure 6. Comparison of observed and modelled $\mathrm{Ca}$ and $\mathrm{Na}$ vertical column abundances: (a) at Kühlungsborn $\left(54^{\circ} \mathrm{N}\right)$ and (b) at Arecibo $\left(18^{\circ} \mathrm{N}\right)$. The Na column observations were made with the Osiris spectrometer on the ODIN satellite (Fan et al., 2007).

cases, there is very good agreement between the model simulations and measurements of both metals. There are several points to note. First, there is a large annual seasonal variation (roughly a factor of 3 between the winter maximum and summer minimum) in the Na layer at $54^{\circ} \mathrm{N}$, which largely disappears at tropical latitudes $\left(18^{\circ} \mathrm{N}\right)$. Second, there is a smaller variation in the $\mathrm{Ca}$ layer at $54^{\circ} \mathrm{N}$ : the layer does not exhibit a winter maximum and summer minimum, but instead a springtime minimum and then a gradual increase during the rest of the year, which is most likely caused by the Ca MIF increasing from spring to autumn. At $18^{\circ} \mathrm{N}$, both model and measurement show almost no seasonal variation. Finally, it is important to note that the column abundances of both layers have been successfully simulated using the common factor of 5 reduction of the Ca and Na MIFs from Carrillo-Sánchez et al. (2016).

\section{$3.4 \mathrm{Ca}^{+}$and $\mathrm{Na}^{+}$ratios}

Figure 7a shows the geometric means of the $\mathrm{Ca}^{+}$and $\mathrm{Na}^{+}$ profiles from the nine rocket profiles described in Sect. 2.3. 


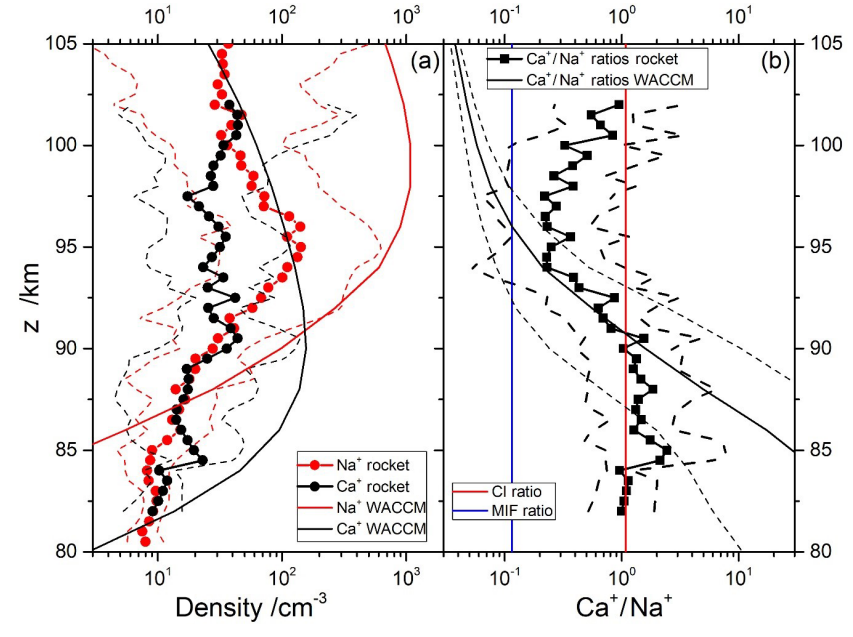

Figure 7. Comparison of observed and modelled $\mathrm{Ca}^{+}$and $\mathrm{Na}^{+}$ density profiles: (a) geometric mean profiles of rocket-borne mass spectrometric measurements of $\mathrm{Ca}^{+}$and $\mathrm{Na}^{+}$(circles) with geometric standard deviations (dashed lines), and WACCM model (thick solid lines); (b) geometric mean profiles of the observed (squares) and modelled (thick solid lines) $\mathrm{Ca}^{+} / \mathrm{Na}^{+}$ratios, with geometric standard deviations (dashed lines). The $\mathrm{Ca} / \mathrm{Na}$ abundance ratio in carbonaceous Ivuna (CI) chondrites (Hutchison, 2004) and the ratio of meteor input functions (Carrillo-Sánchez et al., 2016) are indicated with red and blue lines, respectively.

Geometric means and standard deviations are used because of the sparse data set available and the natural variability of the ion profiles. The $\mathrm{Ca}^{+}$and $\mathrm{Na}^{+}$profiles essentially overlap between 80-91 and 100-105 km. Between 91 and $100 \mathrm{~km}, \mathrm{Na}^{+}$is in excess by up to a factor of 6 . Figure $7 \mathrm{a}$ also shows the predicted ion profiles from WACCM-Ca and WACCM-Na, sampled at the locations of the rocket flights; comparisons of WACCM simulations with rocket flights at 38,51 and $68^{\circ} \mathrm{N}$ are illustrated in Fig. S4 in the Supplement. Note that each WACCM profile is the monthly mean around the local time of the rocket flight. WACCM-Ca agrees with the measured $\mathrm{Ca}^{+}$profile below $82 \mathrm{~km}$ and above $97 \mathrm{~km}$, but overestimates the $\mathrm{Ca}^{+}$density in between, though generally not by more than a factor of 2 outside the geometric standard deviation. The WACCM-Na simulation agrees less well with the rocket measurements of $\mathrm{Na}^{+}$: there is reasonable agreement between 86 and $92 \mathrm{~km}$, but the model then overestimates $\mathrm{Na}^{+}$by up to an order of magnitude outside the geometric standard deviation. Nevertheless, WACCM does correctly predict that the $\mathrm{Na}^{+}$excess over $\mathrm{Ca}^{+}$starts around $91 \mathrm{~km}$.

More relevant for this study is the $\mathrm{Ca}^{+} / \mathrm{Na}^{+}$ratio, which is illustrated in Fig. 7b. This shows that the ratio is roughly 1.0 below $90 \mathrm{~km}$, and falls to 0.3 between 93 and $100 \mathrm{~km}$. Note that the geometric standard deviation of the ratio is significantly smaller than the standard deviations of the individual profiles, which is expected because to some extent both ions will be subject to the same transport processes in the MLT. The modelled ratio agrees with the measured ratio between 84 and $98 \mathrm{~km}$, but is too large below $84 \mathrm{~km}$ and too small above $98 \mathrm{~km}$. Both of these deviations appear to be largely due to the modelled $\mathrm{Na}^{+}$(Fig. 7a). The significant under-prediction of $\mathrm{Na}^{+}$below $85 \mathrm{~km}$ may indicate that further work on its ion-molecule chemistry is needed, and the large over-prediction above $98 \mathrm{~km}$ may result from differential electro-dynamical transport of the lighter $\mathrm{Na}^{+}$compared with $\mathrm{Ca}^{+}$, which is not represented in WACCM (Feng et al., 2013).

Figure $7 \mathrm{~b}$ also compares the $\mathrm{Ca}^{+} / \mathrm{Na}^{+}$ratio with the $\mathrm{CI}$ relative abundance of these elements (red line), and the $\mathrm{Ca} / \mathrm{Na}$ ablation ratio from our recent study of the astronomical dust sources contributing to the cosmic dust input (Carrillo-Sánchez et al., 2016). This MIF ratio is depicted by the blue line. Note that the difference between the two lines, which is almost 1 order of magnitude, demonstrates the differential ablation of refractory $\mathrm{Ca}$ compared with relatively volatile $\mathrm{Na}$. A striking feature of this plot is that the rocketmeasured $\mathrm{Ca}^{+} / \mathrm{Na}^{+}$ratio is higher than the MIF ratio at all altitudes. This underlines the point that whereas $\mathrm{Ca}^{+}$ions are somewhat enriched relative to $\mathrm{Na}^{+}$when benchmarked against their MIFs, $\mathrm{Ca}$ atoms are severely depleted relative to $\mathrm{Na}$ by a factor of more than 100 , and more than 10 against the MIF ratio.

\subsection{Global column abundances}

Figure 8a illustrates the seasonal variation of the Ca column abundance as a function of latitude. The data in this figure are listed in Table S4 in the Supplement. As discussed in Sect. 3.4 and illustrated in Fig. 6, there is good agreement between WACCM and lidar observations at 18 and $54^{\circ} \mathrm{N}$. The original $\mathrm{Ca}$ layer observations were made at Observatoire de Haute-Provence $\left(44^{\circ} \mathrm{N}\right)$, where the average column abundance of Ca between late July and December over a 5-year period (1982-1987) was found to be $(2.7 \pm 1.7) \times 10^{7} \mathrm{~cm}^{-2}$ (Granier et al., 1989). This compares well with the WACCM$\mathrm{Ca}$ average of $2.4 \times 10^{7} \mathrm{~cm}^{-2}$ during the same part of the year. Qian and Gardner (1995) made 8 nights of measurements at Urbana, Illinois $\left(40^{\circ} \mathrm{N}\right)$, between late October 1992 and January 1993. The Ca abundance on these nights ranged from $2.1 \times 10^{7}$ to $1.1 \times 10^{8} \mathrm{~cm}^{-2}$, which encompasses the model average of $2.5 \times 10^{7} \mathrm{~cm}^{-2}$.

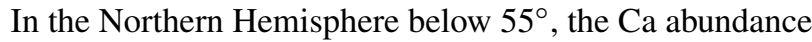
largely follows the Ca MIF, with a minimum in spring and a maximum in autumn (see Fig. S2). At higher latitudes, a combination of chemistry and transport causes a larger variation with a minimum in summer and maximum in winter. One important aspect is photo-ionization (Reaction R38): Ca atoms have an $e$-folding lifetime against photo-ionization of only $5.6 \mathrm{~h}$. Thus in the summer at high latitudes that are continuously sunlit, $\mathrm{Ca}$ is efficiently ionized on the topside of the neutral layer. This leads to the centroid height of the layer 
(a) WACCM-Ca $\mathrm{Ca}\left(10^{7} \mathrm{~cm}^{-2}\right)$

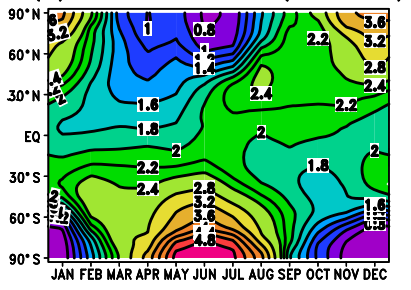

(b) WACCM-Ca $\mathrm{Ca}^{+}\left(10^{7} \mathrm{~cm}^{-2}\right)$

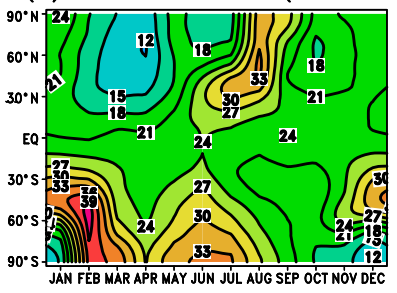

(c) WACCM $\mathrm{Ca} / \mathrm{Na}$

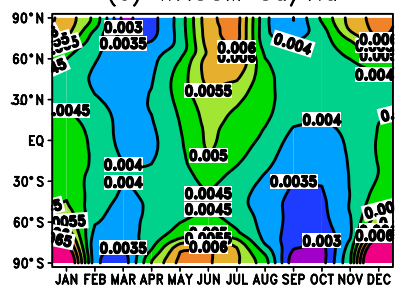

(d) WACCM $\mathrm{Ca}^{+} / \mathrm{Na}^{+}$

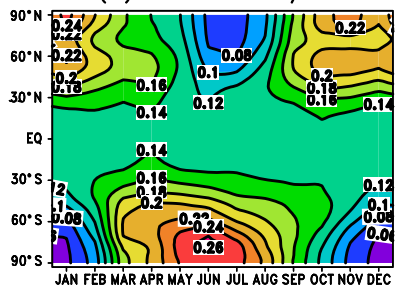

Figure 8. Diurnally averaged column abundances predicted by WACCM, plotted as a function of latitude and month: (a) $\mathrm{Ca}$, (b) $\mathrm{Ca}^{+}$, (c) ratio of $\mathrm{Ca} / \mathrm{Na}$, and (d) ratio of $\mathrm{Ca}^{+} / \mathrm{Na}^{+}$.

moving down by $2-3 \mathrm{~km}$ in summer at high latitudes, and the root-mean-square width of the layer decreasing by about $2 \mathrm{~km}$ (Fig. S3). As shown in Table 1, none of the reactions apart from Reaction (R16) (which is too slow to be significant in the MLT) has a large enough activation energy to cause much temperature-dependent variation to $\mathrm{Ca}$, unlike $\mathrm{Na}$ (Marsh et al., 2013a) and Fe (Viehl et al., 2016).

The other important factor in the high-latitude seasonal variation is the meridional transport in the MLT, which converges over the winter pole and diverges over the summer pole (Plane et al., 2015). The long-range transport of $\mathrm{Ca}^{+}$ ions $(\mathrm{Ca}$ atoms are too short-lived; see Sect. 3.2) will therefore lead to an accumulation of $\mathrm{Ca}^{+}$, and hence $\mathrm{Ca}$, over the winter pole and vice versa. A similar, but more pronounced, effect has been seen in the $\mathrm{Na}$ and Fe layers (Gardner et al., 2005). Figure S5 in the Supplement contains corresponding plots to Fig. 8a for $\mathrm{Na}$, illustrating this point, and also the good agreement between the measured variation of the $\mathrm{Na}$ column abundance using a combination of satellite and lidar data (Dawkins et al., 2015), and WACCM-Na with the Na MIF shown in Fig. 3 and revised Na chemistry (GómezMartín et al., 2016, 2017b).

Figure $8 \mathrm{~b}$ illustrates the global variation of the $\mathrm{Ca}^{+}$column abundance. The data in this figure are listed in Table S4 in the Supplement. Although the interplay between transport and chemistry makes the situation in the Northern Hemisphere at high latitudes more complex, dynamics seem to control the $\mathrm{Ca}^{+}$(and Ca) seasonal variation over Antarctica. The global seasonal $\mathrm{Ca}^{+} / \mathrm{Ca}$ seasonal average is 11.0.

Figure $8 \mathrm{c}$ and $\mathrm{d}$ illustrate the modelled global variation of the $\mathrm{Ca} / \mathrm{Na}$ and $\mathrm{Ca}^{+} / \mathrm{Na}^{+}$ratios, respectively. The most important point to take from these figures is that the model correctly predicts the very small neutral ratio and much larger

ion ratio: the global seasonal averages are around 0.0043 and 0.14 , respectively. As discussed in the Introduction, explaining this huge difference was one of the main goals of the study. Interestingly, the model predicts a small semiannual variation in the $\mathrm{Ca} / \mathrm{Na}$ ratio at all latitudes, whereas the $\mathrm{Ca}^{+} / \mathrm{Na}^{+}$exhibits a more significant annual trend with a summer minimum and winter maximum at middle to high latitudes.

\section{Conclusions}

There were three objectives in the present study. The first was to incorporate the comprehensive new database of neutral and ion-molecule reactions of Ca pertinent to the MLT (Table 1), together with a new meteoric input function for $\mathrm{Ca}$ (Carrillo-Sánchez et al., 2016) that had been validated experimentally (Gómez-Martín et al., 2017a), into a global chemistry-climate model. The second objective was then to explain the more than 100-fold depletion of atomic Ca relative to Na compared with their relative CI abundance, and the third was to explain why the $\mathrm{Ca}^{+}$ion abundance is depleted by only a factor of $\sim 3$ with respect to $\mathrm{Na}^{+}$between 90 and $100 \mathrm{~km}$.

In fact, these seemingly contradictory features of $\mathrm{Ca}$ and $\mathrm{Ca}^{+}$are linked. Ca ablates almost 1 order of magnitude less efficiently than $\mathrm{Na}$ (Carrillo-Sánchez et al., 2016). However, $\mathrm{Ca}$ ionizes more efficiently than the other meteoric metals: it photo-ionizes 2.5 times faster and charge-transfers 5 times faster than $\mathrm{Na}$ with the dominant MLT ion $\mathrm{NO}^{+}$(Plane et al., 2015). This increases the $\mathrm{Ca}^{+} / \mathrm{Na}^{+}$ratio from the ablation ratio of 0.12 to 0.3 in the $92-100 \mathrm{~km}$ height range.

In contrast with the ions, two neutral $\mathrm{Ca}$ species $-\mathrm{CaOH}$ and $\mathrm{CaCO}_{3}$ - have large dipole moments and form stable oxides with $\mathrm{O}_{2}$. Although $\mathrm{O}_{2} \mathrm{CaOH}$ and $\mathrm{O}_{2} \mathrm{CaCO}_{3}$ recycle back to $\mathrm{CaOH}$ and $\mathrm{CaCO}_{3}$ via reactions with $\mathrm{O}$ above the atomic $\mathrm{O}$ shelf around $82 \mathrm{~km}$, they then rapidly recombine again with $\mathrm{O}_{2}$, thus forming stable holding cycles. We have shown this experimentally in the case of $\mathrm{CaOH}$ (Gómez-Martín and Plane, 2017), and for $\mathrm{CaCO}_{3}$ in the present study using electronic structure theory coupled with statistical rate theory. Most of the neutral $\mathrm{Ca}$ is therefore held in the $\mathrm{CaOH}$ and $\mathrm{CaCO}_{3}$ holding cycles, enabling rapid loss through polymerization into meteoric smoke particles. This explains the unexpectedly low abundance of neutral Ca atoms in the MLT, which was first observed more than 30 years ago (Granier et al., 1985).

Data availability. The rocket flight data were kindly provided by Ernest Kopp (University of Bern). The WACCM model and data input are available through a subversion repository at https://svn-ccsm-release.cgd.ucar.edu/ (last access: 10 February 2017). The MERRA-2 data sets used for the specified dynamics in WACCM were provided by the Climate Data Gateway at National Center for Atmospheric Research 
(https://www.earthsystemgrid.org/, last access: 15 August 2018). The WACCM, lidar and rocket data sets generated for this work have been archived at the Leeds University PetaByte Environmental Tape Archive and Library (PETAL; http://www.see.leeds.ac.uk/business-and-consultation/facilities/ petabyte-environmental-tapearchive-and-library-petal, last access: 21 March 2018). The electronic structure theory calculations, additional WACCM-Ca results and a table of the Ca global column abundance climatology are included in the Supplement.

Supplement. The supplement related to this article is available online at: https://doi.org/10.5194/acp-18-14799-2018-supplement.

Author contributions. JMCP carried out the theoretical calculations and chemical model development. WF designed the WACCM model experiments and performed the simulations. JCGM contributed to the $\mathrm{Ca}$ kinetic scheme and analysed the rocket data. MG and SR processed the lidar data. JMCP prepared the paper with contributions from all co-authors.

Competing interests. The authors declare that they have no conflict of interest.

Special issue statement. This article is part of the special issue "Layered phenomena in the mesopause region (ACP/AMT interjournal SI)". It is a result of the LPMR workshop 2017 (LPMR2017), Kühlungsborn, Germany, 18-22 September 2017.

Acknowledgements. This work was supported by the European Research Council (project 291332 - CODITA). Shikha Raizada acknowledges NSF grant 1839012 to the Arecibo Observatory, which is operated by the University of Central Florida under a cooperative agreement with the National Science Foundation (AST-1744119), and in alliance with Yang Enterprises and Ana G. Méndez Universidad Metropolitana.

Edited by: Andreas Engel

Reviewed by: two anonymous referees

\section{References}

Ahmad, I., Baig, M. A., and Hormes, J.: Measurement of oscillatorstrengths of the principal series of calcium, Phys. Rev. A, 49, 3419-3425, https://doi.org/10.1103/PhysRevA.49.3419, 1994.

Alpers, M., Höffner, J., and von Zahn, U.: Upper Atmosphere Ca and $\mathrm{Ca}^{+}$at Mid-Latitudes: First Simultaneous and CommonVolume Lidar Observations, Geophys. Res. Lett., 23, 567-570, https://doi.org/10.1029/96GL00372, 1996.

Bones, D. L., Gerding, M., Höffner, J., Gómez-Martín, J. C., and Plane, J. M. C.: A study of the dissociative recombination of $\mathrm{CaO}^{+}$with electrons: Implications for Ca chemistry in the upper atmosphere, Geophys. Res. Lett., 43, 12333-12339, https://doi.org/10.1002/2016GL071755, 2016a.

Bones, D. L., Gómez-Martín, J. C., Empson, C. J., CarrilloSánchez, J. D., James, A. D., Conroy, T. P., and Plane, J. M. C.: A novel instrument to measure differential ablation of meteorite samples and proxies: The Meteoric Ablation Simulator (MASI), Rev. Sci. Instr., 87, 094504, https://doi.org/10.1063/1.4962751, $2016 b$.

Broadley, S. L. and Plane, J. M. C.: A kinetic study of reactions of calcium-containing molecules with $\mathrm{O}$ and $\mathrm{H}$ atoms: implications for calcium chemistry in the upper atmosphere, Phys. Chem. Chem. Phys, 12, 9095-9107, https://doi.org/10.1039/c004451b, 2010.

Broadley, S. L., Vondrak, T., and Plane, J. M. C.: A kinetic study of the reactions of $\mathrm{Ca}^{+}$ions with $\mathrm{O}_{3}, \mathrm{O}_{2}, \mathrm{~N}_{2}$, $\mathrm{CO}_{2}$ and $\mathrm{H}_{2} \mathrm{O}$, Phys. Chem. Chem. Phys, 9, 4357-4369, https://doi.org/10.1039/b704920j, 2007.

Broadley, S. L., Vondrak, T., Wright, T. G., and Plane, J. M. C.: A kinetic study of Ca-containing ions reacting with $\mathrm{O}, \mathrm{O}_{2}$, $\mathrm{CO}_{2}$ and $\mathrm{H}_{2} \mathrm{O}$ : implications for calcium ion chemistry in the upper atmosphere, Phys. Chem. Chem. Phys, 10, 5287-5298, https://doi.org/10.1039/b805356a, 2008.

Campbell, M. L. and Plane, J. M. C.: Kinetic study of the gas-phase reaction of $\mathrm{Ca}\left({ }^{1} \mathrm{~S}_{0}\right)$ with $\mathrm{O}_{2}$ from 296 to $623 \mathrm{~K}$, J. Phys. Chem. A, 105, 3515-3520, https://doi.org/10.1021/jp003808e, 2001.

Carrillo-Sánchez, J. D., Nesvorný, D., Pokorný, P., Janches, D., and Plane, J. M. C.: Sources of cosmic dust in the Earth's atmosphere, Geophys. Res. Lett., 43, 11979-11986, https://doi.org/10.1002/2016gl071697, 2016.

Clemesha, B. R., Simonich, D. M., Batista, P. P., and Kirchhoff, V.: The Diurnal Variation of Atmospheric Sodium, J. Geophys. Res., 87, 181-186 10.1029/JA087iA01p00181, 1982.

Dawkins, E. C. M., Plane, J. M. C., Chipperfield, M. P., and Feng, W.: The near-global mesospheric potassium layer: Observations and modeling, J. Geophys. Res.-Atmos., 120, 79757987, https://doi.org/10.1002/2015jd023212, 2015.

Fan, Z. Y., Plane, J. M. C., Gumbel, J., Stegman, J., and Llewellyn, E. J.: Satellite measurements of the global mesospheric sodium layer, Atmos. Chem. Phys., 7, 4107-4115, https://doi.org/10.5194/acp-7-4107-2007, 2007.

Fegley, B. and Cameron, A. G. W.: A vaporization model for iron silicate fractionation in the Mercury protoplanet, Earth Planet. Sc. Lett., 82, 207-222, https://doi.org/10.1016/0012821x(87)90196-8, 1987.

Feng, W., Marsh, D. R., Chipperfield, M. P., Janches, D., Höffner, J., Yi, F., and Plane, J. M. C.: A global atmospheric model of meteoric iron, J. Geophys. Res., 118, 9456-9474, https://doi.org/10.1002/jgrd.50708, 2013.

Feng, W. H., Kaifler, B., Marsh, D. R., Hooffner, J., Hoppe, U. P., Williams, B. P., and Plane, J. M. C.: Impacts of a sudden stratospheric warming on the mesospheric metal layers, J. Atmos. Sol.-Terr. Phy., 162, 162-171, https://doi.org/10.1016/j.jastp.2017.02.004, 2017.

Frisch, M. J., Trucks, G. W., Schlegel, H. B., Scuseria, G. E., Robb, M. A., Cheeseman, J. R., Scalmani, G., Barone, V., Mennucci, B., Petersson, G. A., Nakatsuji, H., Caricato, M., Li, X., Hratchian, H. P., Izmaylov, A. F., Bloino, J., Zheng, G., Sonnenberg, J. L., Hada, M., Ehara, M., Toyota, K., Fukuda, R., Hasegawa, J., Ishida, M., Nakajima, T., Honda, Y., Kitao, O., 
Nakai, H., Vreven, T., Montgomery Jr., J. A., Peralta, J. E., Ogliaro, F., Bearpark, M. J., Heyd, J., Brothers, E. N., Kudin, K. N., Staroverov, V. N., Kobayashi, R., Normand, J., Raghavachari, K., Rendell, A. P., Burant, J. C., Iyengar, S. S., Tomasi, J., Cossi, M., Rega, N., Millam, N. J., Klene, M., Knox, J. E., Cross, J. B., Bakken, V., Adamo, C., Jaramillo, J., Gomperts, R., Stratmann, R. E., Yazyev, O., Austin, A. J., Cammi, R., Pomelli, C., Ochterski, J. W., Martin, R. L., Morokuma, K., Zakrzewski, V. G., Voth, G. A., Salvador, P., Dannenberg, J. J., Dapprich, S., Daniels, A. D., Farkas, Ö., Foresman, J. B., Ortiz, J. V., Cioslowski, J., and Fox, D. J.: Gaussian 09, Gaussian, Inc., Wallingford, CT, USA, 2009.

Gardner, C. S., Plane, J. M. C., Pan, W. L., Vondrak, T., Murray, B. J., and Chu, X. Z.: Seasonal variations of the $\mathrm{Na}$ and Fe layers at the South Pole and their implications for the chemistry and general circulation of the polar mesosphere, J. Geophys. Res., 110, D1030210, https://doi.org/10.1029/2004JD005670, 2005.

Gardner, C. S., Liu, A. Z., and Guo, Y.: Vertical and horizontal transport of mesospheric Na: Implications for the mass influx of cosmic dust, J. Atmos. Sol.-Terr. Phy., 162, 192-202, https://doi.org/10.1016/j.jastp.2016.07.013, 2016.

Gerding, M., Alpers, M., von Zahn, U., Rollason, R. J., and Plane, J. M. C.: Atmospheric $\mathrm{Ca}$ and $\mathrm{Ca}^{+}$layers: Midlatitude observations and modeling, J. Geophys. Res., 105, 27131-27146, https://doi.org/10.1029/2000JA900088, 2000.

Gerding, M., Alpers, M., Höffner, J., and von Zahn, U.: Sporadic $\mathrm{Ca}$ and $\mathrm{Ca}^{+}$layers at mid-latitudes: Simultaneous observations and implications for their formation, Ann. Geophys., 19, 47-58, https://doi.org/10.5194/angeo-19-47-2001, 2001.

Glowacki, D. R., Liang, C.-H., Morley, C., Pilling, M. J., and Robertson, S. H.: MESMER: An Open-Source Master Equation Solver for Multi-Energy Well Reactions, J. Phys. Chem. A, 116, 9545-9560, https://doi.org/10.1021/jp3051033, 2012.

Gómez-Martín, J. C. and Plane, J. M. C.: Reaction Kinetics of $\mathrm{CaOH}$ with $\mathrm{H}$ and $\mathrm{O}_{2}$ and $\mathrm{O}_{2} \mathrm{CaOH}$ with O: Implications for the Atmospheric Chemistry of Meteoric Calcium, ACS Earth Space Chem., 1, 431-441, https://doi.org/10.1021/acsearthspacechem.7b00072, 2017.

Gómez-Martín, J. C., Garraway, S. A., and Plane, J. M. C.: Reaction Kinetics of Meteoric Sodium Reservoirs in the Upper Atmosphere, J. Phys. Chem. A, 120, 1330-1346, https://doi.org/10.1021/acs.jpca.5b00622, 2016.

Gómez-Martín, J. C., Bones, D. L., Carrillo-Sánchez, J. D., James, A. D., Trigo-Rodriguez, J. M., Fegley, B., and Plane, J. M. C.: Novel Experimental Simulations of the Atmospheric Injection of Meteoric Metals, Astrophys. J., 836, 212, https://doi.org/10.3847/1538-4357/aa5c8f, 2017a.

Gómez-Martín, J. C., Seaton, C., de Miranda, M. P., and Plane, J. M. C.: The Reaction between Sodium Hydroxide and Atomic Hydrogen in Atmospheric and Flame Chemistry, J. Phys. Chem. A, 121, 7667-7674, https://doi.org/10.1021/acs.jpca.7b07808, $2017 b$.

Granier, C., Jegou, J. P., and Megie, G.: Resonant lidar detection of $\mathrm{Ca}$ and $\mathrm{Ca}^{+}$in the upper atmosphere, Geophys. Res. Lett., 12, 655-658, https://doi.org/10.1029/GL012i010p00655, 1985.

Granier, C., Jegou, J. P., and Megie, G.: Atomic and ionic calcium in the Earth's upper atmosphere, J. Geophys. Res., 94, 9917-9924, https://doi.org/10.1029/JD094iD07p09917, 1989.
Grebowsky, J. M. and Aikin, A. C.: In situ measurements of meteoric ions, in: Meteors in the earth's atmosphere, edited by: Murad, E., and Williams, I. P., Cambridge University Press, Cambridge, UK, 189-214, 2002.

Helmer, M., Plane, J. M. C., and Allen, M. R.: A Kinetic Investigation of the Reaction $\mathrm{Ca}+\mathrm{O}_{3}$ over the TemperatureRange 213 K-383 K, J. Chem. Soc.-Faraday Trans., 89, 763-769, https://doi.org/10.1039/FT9938900763, 1993.

Herrmann, U., Eberhardt, P., Hidalgo, M. A., Kopp, E., and Smith, L. G.: Metal ions and isotopes in sporatic E-layers during the Perseid meteor shower, in: Space Research, edited by: Rycroft, M. J., Pergamon, Oxford, UK, 249-252, 1978.

Hurrell, J. W., Holland, M. M., Gent, P. R., Ghan, S., Kay, J. E., Kushner, P. J., Lamarque, J. F., Large, W. G., Lawrence, D., Lindsay, K., Lipscomb, W. H., Long, M. C., Mahowald, N., Marsh, D. R., Neale, R. B., Rasch, P., Vavrus, S., Vertenstein, M., Bader, D., Collins, W. D., Hack, J. J., Kiehl, J., and Marshall, S.: The Community Earth System Model A Framework for Collaborative Research, B. Am. Meterol. Soc., 94, 1339-1360, https://doi.org/10.1175/bams-d-12-00121.1, 2013.

Hutchison, R.: Meteorites: A Petrologic, Chemical and Isotopic Synthesis Cambridge Planetary Science Series, Cambridge University Press, Cambridge, UK, 2004.

Istomin, V. G.: Ions of extra-terrestrial origin in the Earth ionosphere Space Res., 3, 209-220, 1963.

Jessberger, E. K., Stephan, T., Rost, D., Arndt, P., Maetz, M., Stadermann, F. J., Brownlee, D. E., Bradley, J. P., and Kurat, G.: Properties of Interplanetary Dust: Information from Collected Samples, in: Interplanetary Dust, edited by: Grün, E., Gustafson, B. S., Dermott, S., and Fechtig, H., Astronomy and Astrophysics Library, Springer Berlin Heidelberg, Germany, 253-294, 2001.

Kopp, E.: On the abundance of metal ions in the lower ionosphere, J. Geophys. Res., 102, 9667-9674, https://doi.org/10.1029/97ja00384, 1997.

Kopp, E. and Herrmann, U.: Ion composition in the lower ionosphere, Ann. Geophys., 2, 83-94, 1984.

Kopp, E., Ramseyer, H., and Björn, L. G.: Positive ion composition and electron density in a combined auroral and NLC event, Adv. Space Res., 4, 157-161, https://doi.org/10.1016/02731177(84)90279-5, 1984.

Kopp, E., André, L., and Smith, L. G.: Positive ion composition and derived particle heating in the lower auroral ionosphere, J. Atmos. Terr. Phys., 47, 301-308, https://doi.org/10.1016/00219169(85)90140-0, 1985a.

Kopp, E., Eberhardt, P., Herrmann, U., and Björn, L. G.: Positive ion composition of the high-latitude summer $\mathrm{D}$ region with noctilucent clouds, J. Geophys. Res.-Atmos., 90, 13041-13053, https://doi.org/10.1029/JD090iD07p13041, 1985 b.

Lamarque, J.-F., Emmons, L. K., Hess, P. G., Kinnison, D. E., Tilmes, S., Vitt, F., Heald, C. L., Holland, E. A., Lauritzen, P. H., Neu, J., Orlando, J. J., Rasch, P. J., and Tyndall, G. K.: CAM-chem: description and evaluation of interactive atmospheric chemistry in the Community Earth System Model, Geosci. Model Dev., 5, 369-411, https://doi.org/10.5194/gmd-5369-2012, 2012.

Lodders, K.: Solar System Abundances and Condensation Temperatures of the Elements, Astrophys. J., 591, 1220-1247, https://doi.org/10.1086/375492, 2003. 
Marsh, D. R., Janches, D., Feng, W., and Plane, J. M. C.: A global model of meteoric sodium, J. Geophys. Res., 118, 11442-11452, https://doi.org/10.1002/jgrd.50870, 2013a.

Marsh, D. R., Mills, M. J., Kinnison, D. E., Lamarque, J.-F., Calvo, N., and Polvani, L. M.: Climate Change from 1850 to 2005 Simulated in CESM1(WACCM), J. Climate, 26, 7372-7391, https://doi.org/10.1175/jcli-d-12-00558.1, 2013 b.

McIlrath, T. J. and Sandeman, R. J.: Revised absolute absorption cross-sections of $\mathrm{CaI}$ at 1886.5 and $1765.1 \AA$, J. Phys. B-At. Mol. Opt., 5, L217-L219, https://doi.org/10.1088/00223700/5/10/007, 1972.

McNeil, W. J., Lai, S. T., and Murad, E.: Models of thermospheric sodium, calcium, and magnesium at the magnetic equator, Adv. Space Res., 21 863-866, https://doi.org/10.1016/S02731177(97)00643-1, 1998.

Meister, J., Eberhardt, P., Herrmann, U., Kopp, E., Hidalgo, M. A., and Sechrist Jr., C. F.: D-region ion composition during the winter anomaly campaign on January 8, 1977, Space Res., XVIII, 155-159, 1978.

Nesvorný, D., Janches, D., Vokrouhlický, D., Pokorný, P., Bottke, W. F., and Jenniskens, P.: Dynamical model for the zodiacal cloud and sporadic meteors, Astrophys. J., 743, 129, https://doi.org/10.1088/0004-637x/743/2/129, 2011.

Plane, J. M. C.: Meteoric calcium, Nat. Chem., 3, 900-900, https://doi.org/10.1038/nchem.1172, 2011.

Plane, J. M. C. and Rollason, R. J.: Kinetic study of the reactions of $\mathrm{CaO}$ with $\mathrm{H}_{2} \mathrm{O}, \mathrm{CO}_{2}, \mathrm{O}_{2}$, and $\mathrm{O}_{3}$ : Implications for calcium chemistry in the mesosphere, J. Phys. Chem. A, 105, 7047-7056, https://doi.org/10.1021/jp010810c, 2001.

Plane, J. M. C. and Whalley, C. L.: A New Model for Magnesium Chemistry in the Upper Atmosphere, J. Phys. Chem. A, 116, 6240-6252, https://doi.org/10.1021/jp211526h, 2012.

Plane, J. M. C., Whalley, C. L., Frances-Soriano, L., Goddard, A., Harvey, J. N., Glowacki, D. R., and Viggiano, A. A.: $\mathrm{O}_{2}\left(a^{1} \Delta_{g}\right)+\mathrm{Mg}, \mathrm{Fe}$, and $\mathrm{Ca}$ : Experimental kinetics and formulation of a weak collision, multiwell master equation with spin-hopping, J. Chem. Phys., 137, 014310, https://doi.org/10.1063/1.4730423, 2012.

Plane, J. M. C., Feng, W., Dawkins, E., Chipperfield, M. P., Höffner, J., Janches, D., and Marsh, D. R.: Resolving the strange behavior of extraterrestrial potassium in the upper atmosphere, Geophys. Res. Lett., 41, 4753-4760, https://doi.org/10.1002/2014GL060334, 2014.

Plane, J. M. C., Feng, W., and Dawkins, E. C. M.: The Mesosphere and Metals: Chemistry and Changes, Chem. Rev., 115, 44974541, https://doi.org/10.1021/cr500501m, 2015.
Qian, J. and Gardner, C. S.: Simultaneous lidar measurements of mesospheric $\mathrm{Ca}, \mathrm{Na}$, and temperature profiles at Urbana, Illinois, J. Geophys. Res., 100, 7453-7461, https://doi.org/10.1029/94JD02748, 1995.

Raizada, S., Tepley, C. A., Aponte, N., and Cabassa, E.: Characteristics of neutral calcium and $\mathrm{Ca}^{+}$near the mesopause, and their relationship with sporadic ion/electron layers at Arecibo, Geophys. Res. Lett., 38, L09103, https://doi.org/10.1029/2011g1047327, 2011.

Raizada, S., Tepley, C. A., Williams, B. P., and Garcia, R.: Summer to winter variability in mesospheric calcium ion distribution and its dependence on Sporadic E at Arecibo, J. Geophys. Res.Space, 117, A02303, https://doi.org/10.1029/2011ja016953, 2012.

Robertson, S. H., Glowacki, D. R., Liang, C.-H., Morley, C., Shannon, R., Blitz, M., and Pilling, M. J.: MESMER (Master Equation Solver for Multi-Energy Well Reactions), available at: http:// sourceforge.net/projects/mesmer (last access: 25 October 2017), 2012.

Rutherford, J. A., Turner, B. R., Vroom, D. A., and Mathis, R. F.: Formation of Calcium ions by charge transfer, J. Chem. Phys., 57, 3087-3091, https://doi.org/10.1063/1.1678723, 1972.

Shull, J. M. and van Steenberg, M.: The ionization equilibrium of astrophysically abundant elements, Astrophys. J. Suppl. S., 48, 95-107, https://doi.org/10.1086/190769, 1982.

Smith, I. W. M.: Kinetics and Dynamics of Elementary Gas Reactions, Butterworths, London, UK, 1980.

Swider, W.: Processes for meteoric elements in the E region, Planet. Space Sci., 17, 1233-1246, https://doi.org/10.1016/00320633(69)90014-2, 1969.

Vallance-Jones, A.: Ca II Emission Lines in the Twilight Spectrum, Nature, 178, 276-277, https://doi.org/10.1038/178276a0, 1956.

Viehl, T. P., Plane, J. M. C., Feng, W., and Hoeffner, J.: The photolysis of $\mathrm{FeOH}$ and its effect on the bottomside of the mesospheric Fe layer, Geophys. Res. Lett., 43, 1373-1381, https://doi.org/10.1002/2015gl067241, 2016.

Vondrak, T., Plane, J. M. C., Broadley, S., and Janches, D.: A chemical model of meteoric ablation, Atmos. Chem. Phys., 8, 70157031, https://doi.org/10.5194/acp-8-7015-2008, 2008.

Zbinden, P. A., Hidalgo, M. A., Eberhahdt, P., and Geiss, J.: Mass spectrometer measurements of the positive ion composition in the D- and E-regions of the ionosphere, Planet. Space Sci., 23, 1621-1642, https://doi.org/10.1016/0032-0633(75)90090-2, 1975. 